Article

\title{
Implementation Barriers for a System of Environmental-Economic Accounting in Developing Countries and Its Implications for Monitoring Sustainable Development Goals
}

\author{
Viktor Pirmana 1,2,*D, Armida Salsiah Alisjahbana ${ }^{2,3}$, Rutger Hoekstra ${ }^{1,4}$ and \\ Arnold Tukker ${ }^{1,5}$ (D) \\ 1 Institute of Environmental Sciences (CML), Leiden University, 2333 CC Leiden, The Netherlands; \\ Hoekstra@MetricsForTheFuture.com (R.H.); tukker@cml.leidenuniv.nl (A.T.) \\ 2 Department of Economics, Faculty of Economics and Business, Padjadjaran University, \\ Jl. Raya Bandung Sumedang Km. 21, Jatinangor, West Java 45363, Indonesia; \\ armida.alisjahbana@unpad.ac.id \\ 3 United Nations-Economic and Social Commission for Asia and the Pacific (UN-ESCAP), \\ The United Nations Building, Rajadamnern Nok Avenue, Bangkok 10200, Thailand \\ 4 MetricsForTheFuture.com, 2351 NN Leiderdorp, The Netherlands \\ 5 Netherlands Organisation for Applied Scientific Research TNO, 2595 DA den Haag, The Netherlands \\ * Correspondence: viktor.pirmana@unpad.ac.id
}

Received: 19 July 2019; Accepted: 31 October 2019; Published: 14 November 2019

check for updates

\begin{abstract}
The desire to include environmental information in national accounts has resulted in the construction of a system of environmental-economic accounting (SEEA). As the international statistical standard for environmental-economic accounting, the SEEA can provide valuable support for monitoring Sustainable Development Goals (SDGs). This study assesses the potential use of the SEEA for monitoring SDGs. This paper shows that, in theory, the potential for this system is significant. However, based on a literature review and survey of SEEA experts, practical problems in implementing the SEEA are significant, especially in developing countries. Such issues include data availability and quality, as well as the availability of funding and human resources. Capacity development is key to establishing successful implementation of the SEEA in developing countries. For example, the World Bank's WAVES program (Wealth Accounting and Valuation of Ecosystem Services) has been instrumental in capacity building in developing countries, which, however, still show great variation in how they implement SEEA.
\end{abstract}

Keywords: sustainable development; SEEA; system of environmental-economic accounting; WAVES; SDG indicators

\section{Introduction}

On 25 September 2015, the Sustainable Development Goals (SDGs) were formally adopted. The SDGs represent a vision of the world in the year 2030 [1]. The SDGs contain 17 goals with 169 underlying targets. They have been complemented by about 232 indicators in various social, economic, and environmental areas developed by the Inter-agency and Expert Group on SDG Indicators (IAEG-SDGs) that was set up by the United Nations Statistical Commission. These 232 indicators are grouped into three tiers (Tier Classification for Global SDG Indicators: https: //unstats.un.org/sdgs/files/Tier_Classification_of_SDG_Indicators_22_May_2019_web.xlsx; accessed on 27 August 2019; there are six indicators that have multiple tiers): 
- Tier 1: The indicator is conceptually clear and has an internationally established methodology; its standards are available, and its data are regularly produced by countries for at least 50 percent of countries and for the population in every region where the indicator is relevant (104 indicators).

- Tier 2: The indicator is conceptually clear, has an internationally established methodology, and standards are available, but data are not regularly produced by countries (88 indicators).

- Tier 3: No internationally established methodology or standards are yet available for the indicator, but the methodology/standards are being (or will be) developed or tested (34 indicators).

As can be seen from the definitions of Tiers 1 and 2, the data availability of each country can be quite different. This obviously has implications for the capacity of each country to monitor the implementation of SDGs. Various reviews of the development of the implementation of SDGs exist, such as the Voluntary National Review (VNR) [1] and several other studies; for instance, those from the Overseas Development Institute [2], the Sustainability Development Solution Network (SDSN) [3], and several others. This body of literature finds that there are various issues with data between countries, such as data that are not comparable between countries, incomplete data, and many data sources that are not yet accessible to the public. This situation obviously has major implications for the process and quality of the monitoring system for SDGs, while a sound monitoring system is one of the key factors needed to support the success of SDG implementation.

The SEEA (System of Environmental-Economic Accounting) is an international standard and integrated framework for accounting of environmental data in a way that is consistent with economic accounting. The SEEA thus provides an opportunity that can be used to monitor a significant number of the SDG related indicators in an integrated and consistent manner across countries.

The WAVES (Wealth Accounting and the Valuation of Ecosystem Services) program of the World Bank, while focusing on wealth and natural capital accounting, has supported various developing countries in developing their environmental and economic accounting systems, and thus will also receive attention in this paper.

Against this background, the objective of this study is threefold. First, we want to assess the potential of SEEA to contribute to monitoring SDG related indicators. Second, we analyze the current level of SEEA implementation, with a focus on developing countries, to see if the monitoring potential related to the first question is actually realized. Third, again with a focus on developing countries, we analyze the implementation barriers for a comprehensive implementation of SEEA.

After this Introduction, this paper is structured as follows. Section 2 describes the methods used in this study. Section 3 summarizes, on the basis of a literature review, reports of international organizations and our assessment of how SEEA can support the monitoring of SDGs. Section 4 discusses the implementation level of SEEA in developed and developing countries, again based on a literature review, the reports of international organizations, and our own survey. Section 5 discusses the challenges in implementing and expanding SEEA and its implication for monitoring SDG indicators. Section 6 summarizes the conclusions of the study.

\section{Methods of the Study}

In general, the method of this study will be based on a literature review, an exploration of reports of international organizations, and a dedicated survey of SEEA data producers in developing countries. Explorations of reports from international institutions and literature studies are focused on all the important information about the SEEA, which includes concepts, their uses, linkages with SDGs, and their potential to be used as tools to support the success of SDGs, especially in terms of monitoring indicators and, finally, regarding the current conditions of the implementation and development of the SEEA globally. Crucial references include, for instance, [4-6].

In addition to the literature search, a survey across experts was conducted. We limited the focus in this survey on developing countries. The assessment was aimed at gathering information on the current conditions of the implementation and development of the SEEA. Moreover, the assessment 
was also intended to solicit opinions about the potential of the SEEA to be used as a tool to support the monitoring of SDG indicators. Specifically, the survey assessment in this study is intended to:

- Assess the current status of the national implementation of environmental-economics accounting programs

- Assess institutional arrangements for the compilation of environmental-economic Accounts

- Identify priorities and future plans for the compilation of Environmental-economic Accounts

- Identify the constraints in starting the compilation and developing of environmental-economic Accounts

- Identify the role of the WAVES program in compiling and developing of environmental-economic accounts

- Identify the possibilities of Environmental-Economic Accounts to support the monitoring of SDG indicators

The questionnaire in this assessment is designed in the form of close ended questions. In this study, questions related to the implementation of environmental-economic accounting include questions about the country's economic environmental accounting program, current scope, and future plans for the development of the environmental-economic accounts, institutional arrangements, inhibiting factors, and technical assistance for the compilation of accounts. Meanwhile, questions regarding the role of the SEEA in supporting the successful implementation of SDGs include respondents' opinions about the potential of Environmental-Economic Accounting to support the monitoring of SDG indicators, as well as which accounts and goals have the most potential to be supported by Environmental-Economic Accounting. The full questionnaire can be found in Appendix A.

Questionnaires were sent to 23 carefully selected experts in developing countries, and 14 responded. They were selected after the authors conducted a web-based search for SEEA experts in developing countries. Based on these findings, the authors chose respondents based on information that they were very familiar with and whether they were involved in the collection and development of SEEA accounts for their country. In addition, the web-based information also showed whether the experts routinely represent their country in international forums on natural capital accounting/SEEA organized by international institutions such as the UN's Natural Capital Accounting Forum.

The chosen respondents had extensive knowledge about the status of SEEA in their respective countries. Respondent affiliation and current job were closely related to the development or publication of SEEA in their countries. In general, we selected respondents affiliated with the National Statistical Institute, which has a specific position directly related to producing/drafting the SEEA publications for their country. We also selected respondents from the WAVES Country Program for their roles as country coordinators for WAVES or as individuals actively involved in it, as well as SEEA experts from academia (see Appendix A, Table A1). A detailed methodological flowchart is given in Figure 1. 


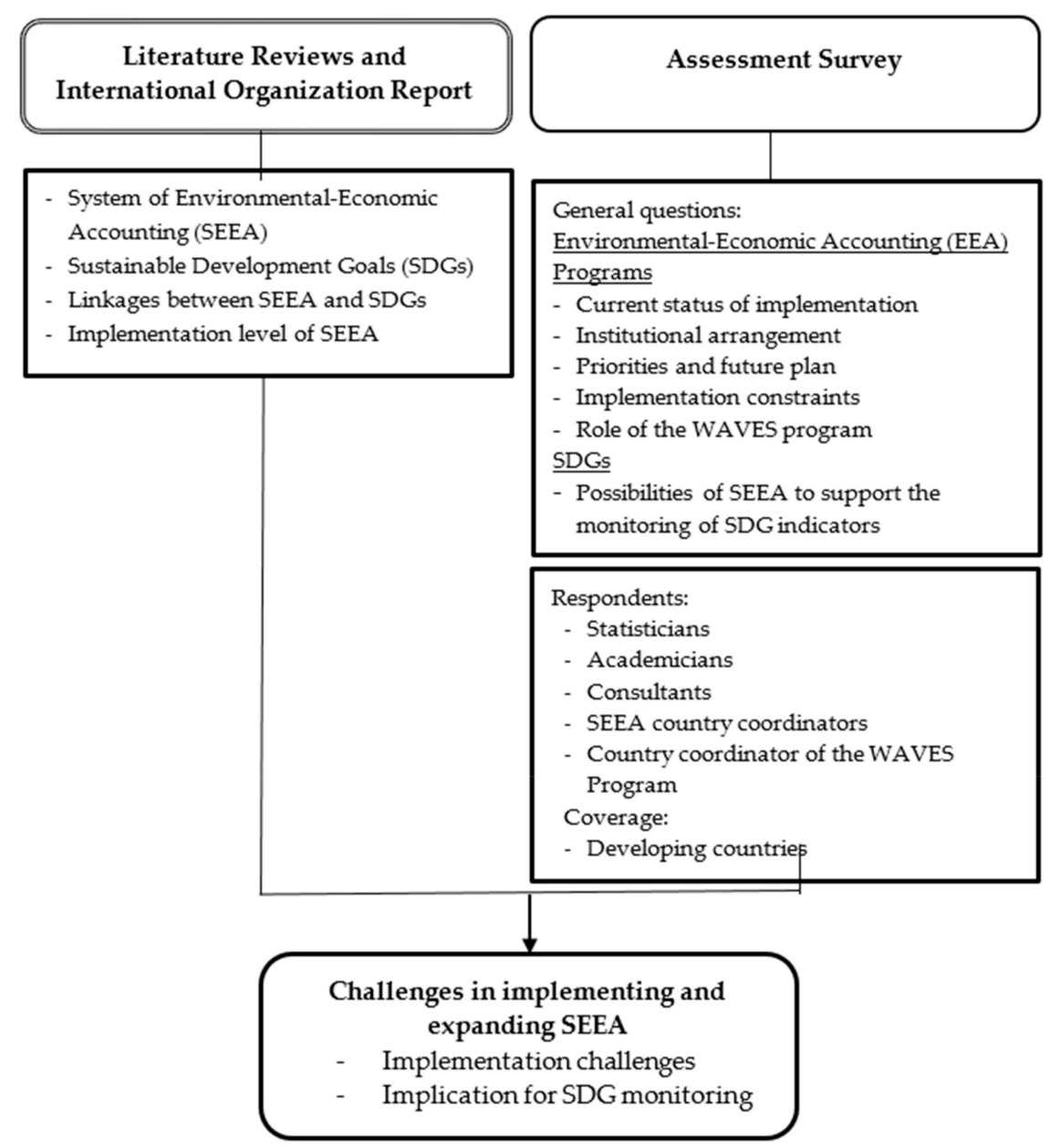

Figure 1. Methodological framework flowchart.

\section{Literature Review and Report Analysis from International Organizations on SEEA and the SDGs}

\subsection{Overview of SEEA}

The SEEA is the international statistical standard for measuring the environment and its relationship with the economy; SEEA is also the most comprehensive framework globally for integrating environmental data into national accounts [4,5,7-9]. The SEEA framework uses an accounting structure similar to that of the Systems of National Account (SNA). To facilitate the integration of environmental and economic statistics, the framework uses concepts, definitions, and classifications consistent with the SNA [10]. As a statistical framework, countries that compile and collect the SEEA will be able to produce reliable environmental-economic datasets that can effectively track progress over time.

The SEEA has become increasingly relevant as the basis for making development policies and evaluations.

- The summary of information in the SEEA (available in the form of aggregates and indicators) can provide information about environmental issues and conditions that are the focus of decision makers.

- More detailed information in the SEEA, for example the main driver of changes in environmental conditions, can be used to provide a deeper understanding of the policy to be taken.

- The data contained in the SEEA can be used to build models and scenarios that can be used to assess different policy scenarios for national and international environmental impacts within a country, between countries, and at the global level. 
The importance of the SEEA is reflected by the attention of international institutions to this matter. For example, the WAVES partnership from the World Bank and the work program by the United Nations Statistics Division (UNSD) promotes sustainable development by mainstreaming the value of natural capital accounting in development planning and national accounting systems. WAVES and UNSD use the SEEA to produce "Natural Capital Accounts" in countries as an important tool to inform economic decision making about natural resources. Both organizations work to build countries' capacities to implement the SEEA and to demonstrate its benefits to policy makers. Furthermore, UNSD together with the United Nations Environment Programme (UNEP), the UN Regional Commission, and the Convention on Biological Diversity (CBD) Secretariat began the SEEA EEA trials and ecosystem assessment in several countries.

\subsection{SDGs and Their Coverage by SEEA}

Since 2015, the global development agenda has shifted from the Millennium Development Goals to SDGs. SDGs accommodate the three well-known economic, social, and environmental dimensions of development. All countries are committed to implementing SDGs, not only because of international demands, but also because many of the SDG targets and objectives are in line with their overall development goals.

One important factor in supporting the successful implementation of SDGs is the ability to monitor progress towards goals. Thus, it is of interest to determine if the SEEA can be used as a tool to accommodate the regular monitoring of SDG indicators.

The role of SEEA as a potential tool for this purpose is mentioned by the UN Committee of Experts on Environmental-Economic Accounting (UNCEEA) [11,12]. UNCEEA endorsed two technical papers to illustrate how SEEA can contribute to SDG monitoring [11,12]. These papers are based on detailed screening of SDG indicators and contain recommendations for compliance with the SEEA. Conclusions are presented in a note on the SEEA entitled "A Statistical Framework to Support SDG Indicators" [12].

The first technical paper [11] considered the need to integrate environmental-economic statistics and the role of SEEA as a necessary conceptual framework. Furthermore, the paper also discussed the benefits for national and global policy-making and the SDG monitoring process following the integration of environmental-economic statistics. Finally, it laid out a transformative roadmap for aligning SDG monitoring procedures and mechanisms with the statistical standards of the SEEA.

The second technical paper [12] illustrated how integrated statistical frameworks, such as the SEEA, can facilitate the production of statistics and indicators by national statistical systems, which can result in higher quality indicators in terms of:

(1) Policy relevance and utility. Indicators are supported by detailed and organized information, which promotes a detailed understanding of the factors that drive change.

(2) Analytical and methodological soundness. SEEA acts as a vehicle for harmonizing methodological inconsistencies across the environmental data production process and enables a coherent comparison of environment statistics with economic statistics.

(3) Measurability and practicality. SEEA can create efficiencies in the data production process [11].

The information from SEEA and SNA can provide valuable support to SDG monitoring and reporting initiatives by (1) supporting the development of Integrated Information Systems for Sustainable Development in countries to produce consistent and internationally comparable statistics and (2) by providing a support structure for a sustainable global SDG monitoring mechanism.

As discussed in the Introduction, to monitor SDG implementation, a long list of 232 indicators was proposed by the Inter-Agency Expert Group on SDGs (IAEG-SDGs) [6]. Implementation of the SDGs requires one to understand the multi-dimensional interdependencies and trade-offs between economic activities and the environment. SEEA, as an international statistical standard, can aid in the design of integrated policies and the monitoring of SDG indicators. This capacity arises from the fact that the SEEA provides a comprehensive methodology for compiling physical and monetary accounts 
for a range of resources, including mineral, energy, water, and timber, and for linking these accounts to information related to the economy [13].

UNCEEA, 2016 [14], sought to investigate the relationship between SEEA and SDG indicators through a broad-brush analysis of indicators related to SDGs that, in principle, can be monitored using SEEA. This broad-brush analysis assessed if and to what extent each indicator could be informed by the existence of SEEA.

This analysis showed that SEEA is a potential monitoring tool for over 50 out of the 232 potential SDG indicators and can support addressing priority issues in each country. According to the analysis, 10 SDGs $(2,6,7,8,9,11,12,14,15,17)$ are related to the SEEA. This analysis used three categories for the degree of relevance of the SDG indicators in terms of the SEEA (Table 1).

Table 1. Potential use of the System of Environmental-Economic Accounting (SEEA) for estimating the Sustainable Development Goals (SDG) indicators and targets.

\begin{tabular}{lc}
\hline \multicolumn{1}{c}{ Category } & Relevant Indicators \\
\hline Indicator as currently proposed can be informed by the SEEA accounts. & 11 indicators \\
\hline $\begin{array}{l}\text { Either current wording and concepts of the indicator need to be aligned } \\
\text { to be SEEA compliant or the indicator needs to be further defined to } \\
\text { ensure SEEA compliance (i.e., detailed definitions added). }\end{array}$ & 23 indicators \\
\hline
\end{tabular}

While the indicator cannot be informed by the SEEA, either: (a) the SEEA can provide important contextual information, and the indicator should be developed with the SEEA approach in mind; or (b) there is some overlap with the SEEA methodology that should be considered when formulating this indicator.

Source: Adapted from the United Nations Committee of Experts on Environmental-Economic Accounting (UNCEEA), (2016) [14]; notes: for complete results, see Appendix A, Table A2.

Adopting the SEEA handbook will ensure that the SDG indicators are internationally comparable, of high quality, and can be integrated into mainstream information systems. Table 2 lists the possible SDG indicators that can be constructed from SEEA databases (see Appendix A, Table A2, for details). In their review, the researchers in [14] further elaborated the SEEA as a tool for designing, implementing, and reviewing evidence-based SDG policies at the country level. They concluded that SEEA could be especially helpful for SDGs related to natural capital (SDGs 6, 13, 14, 15, 17) and to sustainable production and consumption (SDGs 2 and 12), energy (SDG 7), economic growth (SDG 8), and sustainable cities (SDG 11).

Table 2 summarizes in more detail which type of SEEA accounts can support monitoring specific SDG goals. The table shows that, as an information system, SEEA plays an important role in most SDGs. It appears that all SEEA accounts are useful for monitoring some of the SDG indicators. For instance, for SDG 6 (clean water and sanitation) and SDG 15 (life on land/ecosystems), many indicators can be directly measured using the SEEA accounts. Indicators such as 6.4.1 (change in water-use efficiency) could, in the future, be provided by an SEEA dataset on the water account, namely the Physical Supply and Use Tables (PSUT) and other accounts in the water accounting manual. SDG 15, 15.1.1 (forest area as a proportion of total land area), for example, can be obtained by using data available in the SEEA-and account. This table also shows that for 10 SDG goals related to SEEA, material accounts are relevant for several indicators spread over nine SDG goals related to SEEA accounts, followed by environmental activity accounts, where these accounts are relevant for some indicators spread over seven goals related to SEEA accounts. Moreover, of the approximately 46 indicators identified as having the potential to be monitored through the SEEA, 20 indicators are classified into Tier 1, 16 indicators into Tier 2, 8 indicators into Tier 3, and 2 indicators included in Tier 1/3 (Table 3). Based on this information, it is clear that the SEEA could potentially have a significant role in supporting the progress and success of SDGs. 
Table 2. Potential use of SEEA to monitor the SDG indicators. SNA, Systems of National Account.

\begin{tabular}{|c|c|c|c|c|c|c|c|c|c|c|c|}
\hline Account & Type of Account & Goal 2 & Goal 6 & Goal 7 & Goal 8 & Goal 9 & Goal 11 & Goal 12 & Goal 14 & Goal 15 & Goal 17 \\
\hline Land & Asset accounts & $\sqrt{ }$ & & & & & $\sqrt{ }$ & & $\sqrt{ }$ & $\sqrt{ }$ & \\
\hline \multirow{3}{*}{ Energy } & $\begin{array}{c}\text { Physical Supply and Use } \\
\text { Tables (PSUT) }\end{array}$ & & & $\sqrt{ }$ & & $\sqrt{ }$ & & & & & \\
\hline & Economic accounts & & & $\sqrt{ }$ & & & & $\sqrt{ }$ & & & \\
\hline & Asset accounts & & & $\sqrt{ }$ & & & & & & & \\
\hline \multirow[t]{2}{*}{ Water } & PSUT + Economic accounts & & $\sqrt{ }$ & & & & & & & & \\
\hline & Asset accounts & & & & & & & & & & \\
\hline \multirow{4}{*}{ Materials } & Material flow accounts & & & & $\sqrt{ }$ & $\sqrt{ }$ & & $\sqrt{ }$ & $\sqrt{ }$ & & \\
\hline & Emissions accounts & & $\sqrt{ }$ & & & & & & & & \\
\hline & Air Emissions accounts & & & $\sqrt{ }$ & & $\sqrt{ }$ & & & & & \\
\hline & Solid Waste accounts & & & & & & $\sqrt{ }$ & $\sqrt{ }$ & & & \\
\hline $\begin{array}{l}\text { Aquatic } \\
\text { resources }\end{array}$ & Asset accounts & & & & & & & & $\sqrt{ }$ & & \\
\hline $\begin{array}{l}\text { Agriculture, } \\
\text { forestry, and } \\
\text { fisheries }\end{array}$ & All & $\sqrt{ }$ & & & & & & & $\sqrt{ }$ & & \\
\hline \multirow{4}{*}{$\begin{array}{l}\text { Environmental } \\
\text { Activities }\end{array}$} & Environmental protection & & & & & & & & & & \\
\hline & Expenditure account & & & & & & $\sqrt{ }$ & & $\sqrt{ }$ & $\sqrt{ }$ & $\sqrt{ }$ \\
\hline & $\begin{array}{l}\text { Resource management } \\
\text { expenditure accounts }\end{array}$ & & & & & & $\sqrt{ }$ & & & & \\
\hline & $\begin{array}{l}\text { Environmental taxes and } \\
\text { subsidies accounts }\end{array}$ & & & & & & & $\sqrt{ }$ & $\sqrt{ }$ & & \\
\hline \multirow{4}{*}{ Ecosystem } & Condition accounts & & & & & & & & & $\sqrt{ }$ & \\
\hline & Ecosystem extent accounts & & $\sqrt{ }$ & & & & & & & $\sqrt{ }$ & \\
\hline & Ecosystem services accounts & & & & & & & & & $\sqrt{ }$ & \\
\hline & Biodiversity accounts & & & & & & & & & $\sqrt{ }$ & \\
\hline \multirow{3}{*}{ UN-SNA } & All & $\sqrt{ }$ & $\sqrt{ }$ & & & $\sqrt{ }$ & & $\sqrt{ }$ & & & \\
\hline & Value added & & & $\sqrt{ }$ & & & & & & & \\
\hline & Tourism & & & & $\sqrt{ }$ & & & $\sqrt{ }$ & & & \\
\hline
\end{tabular}

Source: Adapted from UN Committee of Experts on Environmental-Economic Accounting (UNCEEA) (2016) [14]; notes: for complete results, see Appendix A, Table A2. 
Table 3. Examples SEEA-relevant SDG indicators.

\begin{tabular}{|c|c|c|}
\hline Indicators & Account & Tier \\
\hline 2.4.1 Proportion of agricultural area under productive and sustainable agriculture & Land + Agriculture, Forestry and Fisheries & Tier 2 \\
\hline 2.a.1 The agriculture orientation index for government expenditures & SNA + Environmental Activities & Tier 1 \\
\hline 6.3.1 Proportion of wastewater safely treated & Water & Tier 2 \\
\hline $\begin{array}{l}\text { 6.4.2 Level of water stress: freshwater withdrawal as a proportion of available } \\
\text { freshwater resources }\end{array}$ & Water & Tier 1 \\
\hline 7.1.1 Proportion of population with access to electricity & Energy & Tier 1 \\
\hline 7.3.1 Energy intensity measured in terms of primary energy and GDP & SNA + Energy & Tier 1 \\
\hline 8.4.1 Material footprint, material footprint per capita, and material footprint per GDP & Materials & Tier 2 \\
\hline 8.9.1 Direct tourism GDP as a proportion of the total GDP and growth rate & SNA & Tier 2 \\
\hline 9.4.1 CO2 emissions per unit of value added & Materials & Tier 1 \\
\hline 11.3.1 Ratio of land consumption rate to population growth rate & Land & Tier 2 \\
\hline $\begin{array}{l}\text { 11.6.1 Proportion of urban solid waste regularly collected and with adequate final } \\
\text { discharge out of the total urban solid waste generated by cities }\end{array}$ & Materials & Tier 2 \\
\hline 12.2.1 Material footprint, material footprint per capita, and material footprint per GDP & Materials & Tier 2 \\
\hline 12.5.1 National recycling rate; tons of material recycled & Materials & Tier 3 \\
\hline 14.4.1 Proportion of fish stocks within biologically sustainable levels & Aquatic Resources & Tier 1 \\
\hline $\begin{array}{l}\text { 14.7.1 Sustainable fisheries as a percentage of GDP in small island developing states in } \\
\text { the least developed countries and all countries }\end{array}$ & Agriculture, Forestry and Fisheries & Tier 1 \\
\hline 15.1.1 Forest area as a proportion of the total land area & Land & Tier 1 \\
\hline $\begin{array}{l}\text { 15.a.1 Official development assistance and public expenditure on conservation and } \\
\text { sustainable use of biodiversity and ecosystems }\end{array}$ & Environmental Activities & Tier $1 / 3$ \\
\hline 17.1.1 Total government revenue as a proportion of GDP by source & Environmental Activities & Tier 1 \\
\hline 17.1.2 Proportion of domestic budget funded by domestic taxes & Environmental Activities & Tier 1 \\
\hline
\end{tabular}

Source: Adapted from: UNCEEA (2016) [14]; for a complete picture, see Appendix A, Table A2. Notes: SDG tier classification taken from the United Nation Statistical Division (UNSD). https://unstats.un.org/sdgs/files/Tier_Classification_of_SDG_Indicators_22_May_2019_web.xlsx, accessed 27 August 2019. 


\subsection{Assessment Survey of the Potential for the SEEA to Support SDG Indicator Monitoring}

Apart from above literature analysis, this study also offers the results of a survey assessing the possibilities of SEEA based environmental-economic accounts to support the achievement of SDGs. This survey aims to elicit opinions about the potentials and challenges of the SEEA as a tool for monitoring SDG indicators. The following conclusions can be drawn from the survey results: All respondents from 14 countries agreed that environmental-economic accounting data can support SDG monitoring. Furthermore, they also believed that all of the SEEA accounts could be potentially used as a tool to support the monitoring of SDG indicators. According to this assessment, the accounts with the most potential to support SDG indicator monitoring were water accounts, energy and emission accounts, and forest accounts (Figure 2).

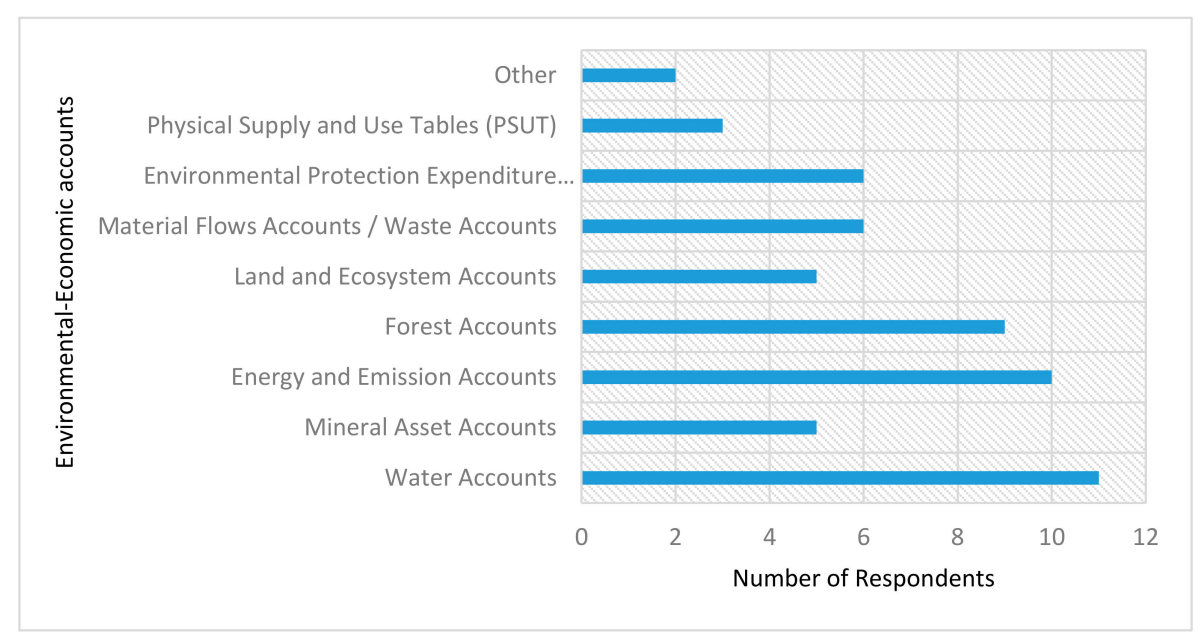

Figure 2. Potential accounts to support SDG indicator monitoring (source: own survey).

The assessment showed that Goal 6, related to the availability and sustainable management of water and sanitation for all, had the most potential to be supported by the existence of environmental-economic accounts, followed by Goal 7 (affordable and clean energy) and Goal 15 (life on land (ecosystem), see Figure 3.

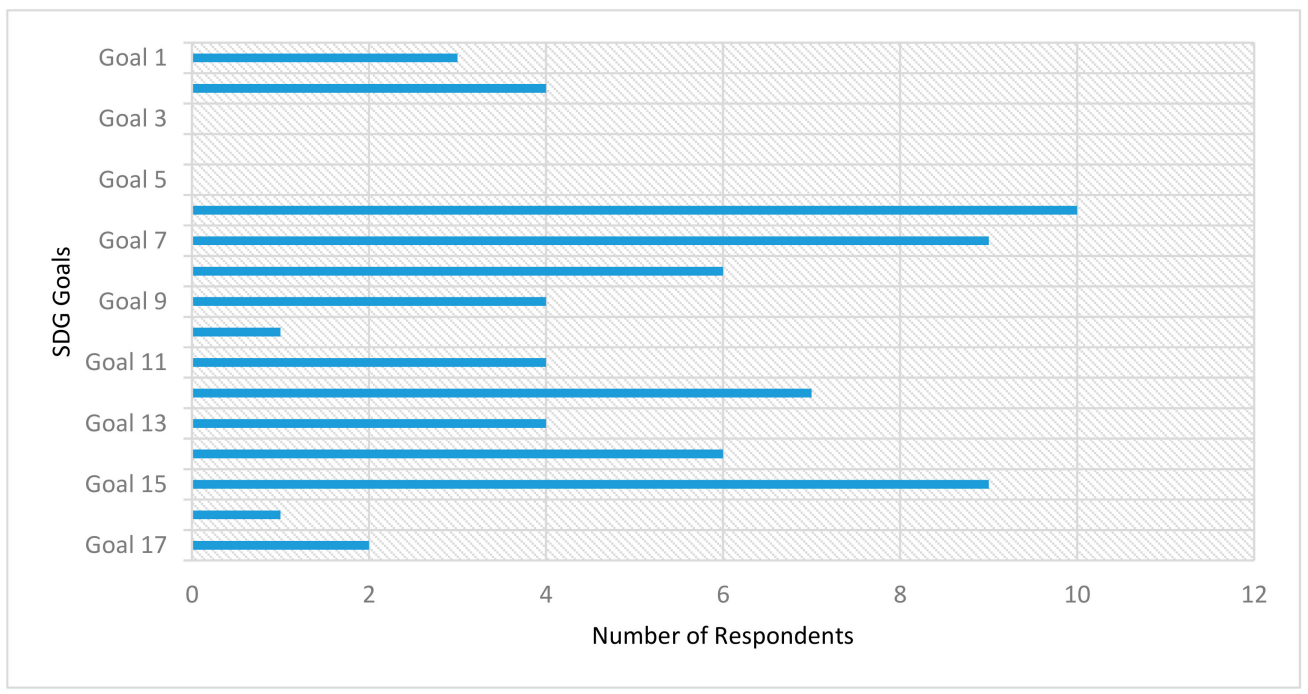

Figure 3. Potential goal of SDGs supported by the existence of the environmental-economic accounts (source: own survey). 


\subsection{Conclusions about the Relationship between SEEA and SDGs}

The analysis of this study clearly confirmed that SEEA, as a standard international statistical framework, has a significant potential to be used as a tool to support the monitoring of SDG indicators. Although not complete and as-yet imperfect, these results suggest that indicators and analytical methods based on SEEA to support the national SDG process exist. Moreover, based on the analysis results, SDG indicators that were potentially supported by the existence of the SEEA were classified into Tiers 1 and 2 (see Table 3). Of the 232 indicators, 50 very important ones were covered by the SEEA. Several indicators, such as 6.4.2 (level of water stress) and 9.4.1 $\left(\mathrm{CO}_{2}\right.$ emissions per unit of value added), were conceptually clear, had an internationally established methodology, and could be informed by the existence of the SEEA (see Table 3 and Appendix A, Table A2 for detail). However, the success of the SEEA in supporting SDGs will depend on countries being able to develop their SEEA-based accounts in a way that is internationally comparable. It is, therefore, relevant to analyze the extent of SEEA implementation and if factors such as complexity, data problems, unfamiliarity, and lack of technical capabilities and skills represent obstacles to the SEEA in enabling SDGs at the country level.

\section{Implementation Levels of SEEA}

\subsection{Introduction to the Implementation of SEEA}

A description of the SEEA implementation in this study was derived from the results of our literature survey (e.g., [3-5,7] and surveys conducted by international organizations such as the UN and the World Bank in the context of its WAVES program [15-21]. In addition, as discussed in the Methods Section, we conducted our own survey to obtain more specific details and information on SEEA implementation compared to the assessment survey conducted by the UN. We discuss the results obtained via these two approaches in the two sections below and end with conclusions.

\subsection{Literature Review and International Reports on SEEA Implementation}

\subsubsection{General Literature Review}

Several studies focused on the level of implementation of SEEA in different countries. A comprehensive example is the work of Edens, de Haan, and Schenau [22], which summarized the environmental accounting experiences by non-EU countries, cross classified by the different chapters of SEEA (Table 4). The countries listed in Table 4 are known to have (or have had) environmental accounting programs. 
Table 4. Experiences outside the EU with environmental accounting.

\begin{tabular}{ccccc}
\hline & Ch3 & Ch4 & Ch5 & Ch6 \\
\hline Australia & Flows ${ }^{\text {a) }}$ & Monetary $^{\text {b) }}$ & Assets ${ }^{\text {c) }}$ & Sequence ${ }^{\text {d) }}$ \\
Botswana & $\mathrm{x}$ & $\mathrm{x}$ & $\mathrm{x}$ & $\mathrm{x}$ \\
Brazil & & & $\mathrm{x}$ & \\
Canada & $\mathrm{x}$ & $\mathrm{x}$ & $\mathrm{x}$ & \\
China & $\mathrm{x}$ & & & $\mathrm{x}$ \\
Colombia & $\mathrm{x}$ & $\mathrm{x}$ & $\mathrm{x}$ & $\mathrm{x}$ \\
India & $\mathrm{x}$ & & $\mathrm{x}$ & $\mathrm{x}$ \\
Indonesia & $\mathrm{x}$ & & $\mathrm{x}$ & $\mathrm{x}$ \\
Japan & $\mathrm{x}$ & $\mathrm{x}$ & $\mathrm{x}$ & $\mathrm{x}$ \\
Jordan & $\mathrm{x}$ & & $\mathrm{x}$ & \\
Mexico & $\mathrm{x}$ & & $\mathrm{x}$ & $\mathrm{x}$ \\
Namibia & & & $\mathrm{x}$ & \\
New Zealand & $\mathrm{x}$ & $\mathrm{x}$ & $\mathrm{x}$ & \\
Philippines & $\mathrm{x}$ & & $\mathrm{x}$ & $\mathrm{x}$ \\
Korea & & & $\mathrm{x}$ & \\
South Africa & $\mathrm{x}$ & $\mathrm{x}$ & $\mathrm{x}$ & $\mathrm{x}$ \\
USA & $\mathrm{x}$ & & $\mathrm{x}$ & $\mathrm{x}$ \\
EU & $\mathrm{x}$ & $\mathrm{x}$ & & \\
\hline
\end{tabular}

Source: Edens B., M. de Haan, and Shenau, S [22]; notes: ${ }^{\text {a) }}$ physical flow accounts; ${ }^{\text {b) }}$ monetary flow accounts; ${ }^{\text {c) }}$ assets accounts; ${ }^{d)}$ sequence of economic accounts (the sequence of economic accounts records a range of transactions between economic units, for example payments of rent on environmental assets that are usefully analyzed from the perspective of institutional sectors rather than by industry or activity).

The overall picture that emerges from Table 4 is that outside the EU, interest in natural resource (asset) accounting is high. This tendency could be attributed to environment related policy perspectives. Edens B., M. de Haan, and Shenau, S [22] noted that policy demands in developing countries should be understood based on the need for resource management of their natural resource endowments and specific security issues related to water and energy. They also stated that the perspective of developing countries differs from that of developed countries, where flow issues of expenditures, economic instruments, resource efficiency, and environmental degradation related economic activities take precedence. Data availability is also an issue for emission accounts because of the need for energy statistics and emission inventories, which may be less readily available in developing countries.

March [4] reviewed the experiences of three industrialized export nations and offered a spectrum of implementation of SEEA integration in Germany, Australia, and China. Germany and Australia are classified as developed countries with long histories in the context of environmental accounting, protection, and regulation. China, by contrast, is a developing nation with rapid growth in economic development and endowed with vast natural capital, but limited regulatory regimes concerning the environment.

March [4] concluded that Germany and Australia, as developed nations, have seen successful adoption and implementation of SEEA to inform their environmental agendas. Germany has a long history on SEEA and has been successful in implementing SEEA. Germany continuously refines its sustainable development indicators and the accounting methods stipulated in its SEEA to inform national policy effectively.

Meanwhile, Australia built a case for policy-makers by educating them about the potential usefulness of SEEA through its initial report, Completing the Picture: Environmental Accounting in Practice (ABS, 2012, in [4]). These efforts led to decision-makers seeing an Australian SEEA as useful for informing Australia's environmental policy going forward.

Moreover, Aoki-Suzuki et al. [23] performed an international comparison of the application of economy wide material flow accounting (EW-MFA) to monitor resource consumption. They found that countries whose policy-makers pay considerable attention to EW-MFA indicators are characterized by 
large resource imports and large net export of manufactured goods. In developing countries, however, much of the data for constructing EW-MFA are available, but collection is fragmented and access limited. These authors also suggested that ensuring the capacity to develop EW-MFA requires first coordinating a national focal point, raising awareness among government officials, training researchers and experts in EW-MFA, and strengthening institutions collecting relevant data.

\subsubsection{United Nation Statistical Division Global Assessment of Environmental-Economic Accounting}

The UNSD offers the most authoritative overview of global SEEA implementation [19-21]. The design of the Global Assessment is to assess the progress made in meeting the targets of the SEEA implementation strategy.

According to the 2017 Global Assessment, the number of countries with an existing program on environmental-economic accounting has increased. Of the 109 surveyed countries, 69 have a program on environmental-economic accounting, corresponding to an increase of about 28 percent compared to the 2014 Global Assessment (Appendix D, Figure A1). This increase was especially high, about 39 percent, for developing countries, while it was only 19 percent for the developed countries. In terms of geographical region, the largest percentage of respondents with an existing program is in Europe and North America ( 88 percent). Meanwhile, Africa has the lowest percentage (36 percent).

The order of importance for most compiled accounts differs between developed and developing countries (Appendix D, Figure A2). In developing countries, the most commonly compiled accounts tend to be energy and water accounts. By contrast, in developed countries, the most commonly compiled accounts are material flow and environmental taxes and subsidies accounts, with a high tendency to focus on energy accounts. Overall, all the global assessments of the UNSD indicated that the most commonly compiled accounts by country do not change for all countries or between developed and developing countries.

Other important findings from the Global Assessment 2017 relate to funding and technical assistance for compiling and developing SEEA. Only 45 of the 69 countries had regular funding for repeat compilation and publication of the accounts [21]. In terms of technical assistance, 65 percent of countries with an environmental-economic accounting program stated that they had received technical assistance from non-governmental organizations, international organizations, or other institutions in compiling and/or developing specific modules.

\subsubsection{Experiences of the WAVES Program Relevant for SEEA Implementation}

The World Bank, one of the institutions that contributed to the SEEA Central Framework, has launched a global partnership to advance natural capital accounting internationally through the Wealth Accounting and Valuation of Ecosystem Services (WAVES) program at the 2010 Convention on Biological Diversity meeting in Nagoya, Japan.

WAVES is intended to implement natural capital accounting using the UN's SEEA in a critical mass of countries, to promote sustainable development by ensuring the normalization of natural resources into development planning and national economic accounts. WAVES works to assist and build the capacity in countries to implement the SEEA and also to demonstrate its benefits to policy-makers [16]. Botswana, Colombia, Costa Rica, Madagascar, and The Philippines were the first core implementing countries to start this program. In late 2013, Guatemala, Indonesia, and Rwanda joined WAVES as core implementing countries.

Since its launch in 2010, WAVES has demonstrated the viability of establishing environmental accounts in low and middle income countries, as well as informing national development plans and policies. In the first five WAVES pilot countries, the program contributed positively in the context of environmental-economic policy. Water accounts have been identified as an instrumental tool for water sector reform in Botswana. Mineral accounts have also been a useful tool in helping the Botswanan government develop a fiscal rule on the management of mineral revenues, a major component of gross domestic product and government revenue. Meanwhile, for Guatemala, forest accounts have 
documented the extent of uncontrolled logging. This account is also used as the basis for formulating the National Strategy for Production and Use of Fuelwood.

Moreover, WAVES [17] reported that Costa Rica has made a significant investment in conserving its abundant natural resources with great success. More than half (52 percent) of the country's area is now covered with forests. Furthermore, more than 90 percent of the country's electricity is generated from renewable resources. The Central Bank is routinely updating and publishing accounts in parallel with these national accounts, especially on water and energy accounts that they can use as information for policymakers related to environmental policy.

There is also substantive UNSD work underway around the world. UNSD work is essential to SEEA development through technical cooperation, which is one of the core functions of the UNSD. They provide support to member states and improve statistical services through advice and training.

\subsection{Assessment of SEEA Implementation in Selected Developing Countries via an Assessment Survey}

The assessment survey of this study, as described earlier, also assessed the extent of SEEA implementation in developing countries, covering general information on their programs of environmental-economic accounting. This survey included questions about institutional infrastructure, subject areas of the account, obstacles to the development and implementation of the programs, and the countries' future plans.

The assessment survey consisted of fourteen experts from fourteen developing countries. Among the fourteen experts, six persons were involved in the WAVES program from the World Bank and eight persons in developing countries without involvement in WAVES. The assessment results showed that energy and emission accounts were the most commonly compiled accounts, followed by water accounts, forest accounts, mineral accounts, and ecosystem and land accounts (Figure 4).

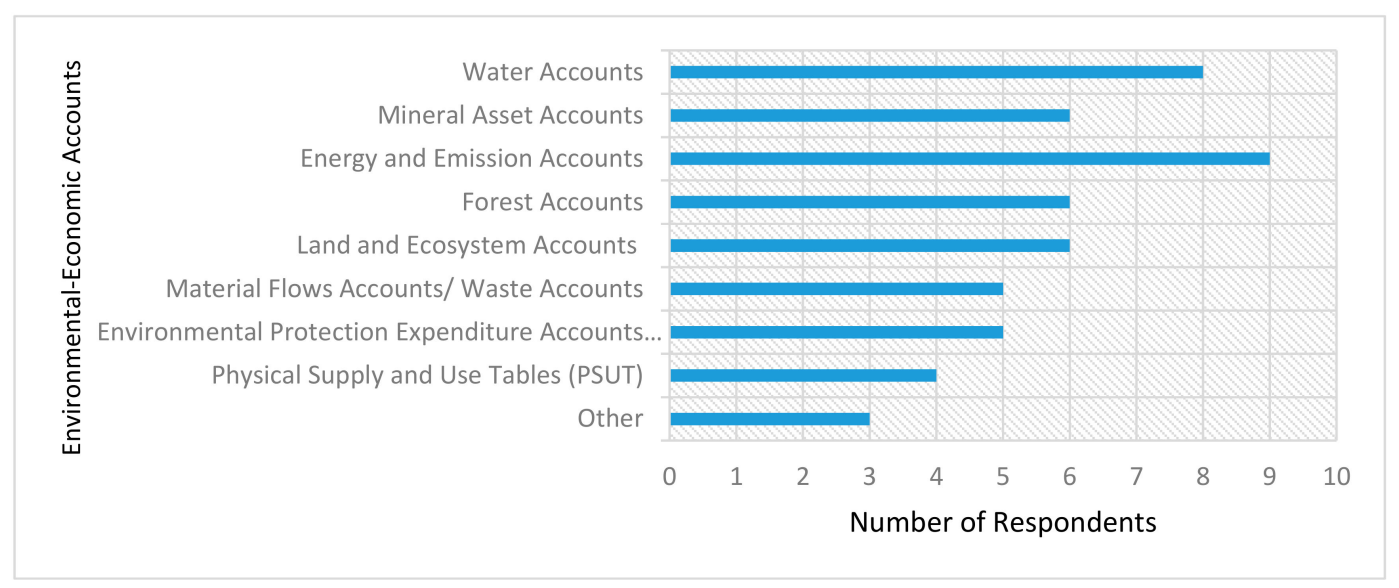

Figure 4. Existence of environmental-economic accounting programs in 14 developing countries (source: own survey).

The most important results of the survey assessment were related to funding issues for the data collection and development of the SEEA. Most respondents (eight out of 14 respondents) stated that they get funding regularly in collecting and developing SEEA accounts, but only a small number of countries surveyed in the assessment survey stated that they get regular funding from the government. For example, Guatemala relies on university funds and funds from external sources (WAVES) to finance the collection and development of SEEA accounts for its country. We can conclude that the problem of routine funding in the collection and development of the SEEA going forward will greatly determine the continuity of program implementation and development for developing countries. Furthermore, the assessment also noted that all respondents whose countries were involved in the collaboration of the WAVES program agreed that international organizations' assistance in the form of funding, technical assistance, and capacity building had a significant role in supporting the progress of 
SEEA development in developing countries. They also stated that water accounts, forest accounts, and land and ecosystem accounts are the accounts most strongly impacted by the existence of the WAVES program.

All respondents, except those from Jamaica and Curacao, noted that their countries plan to expand the compilation of their environmental-economic accounts. Moreover, the assessment survey also found that their priorities going forward are water accounts, land and ecosystem accounts, and forest accounts (Figure 5). For example, Bangladesh plans to develop water accounts, forest accounts, land and ecosystem accounts, and Environmental Protection Expenditure Accounts (EPEAs).

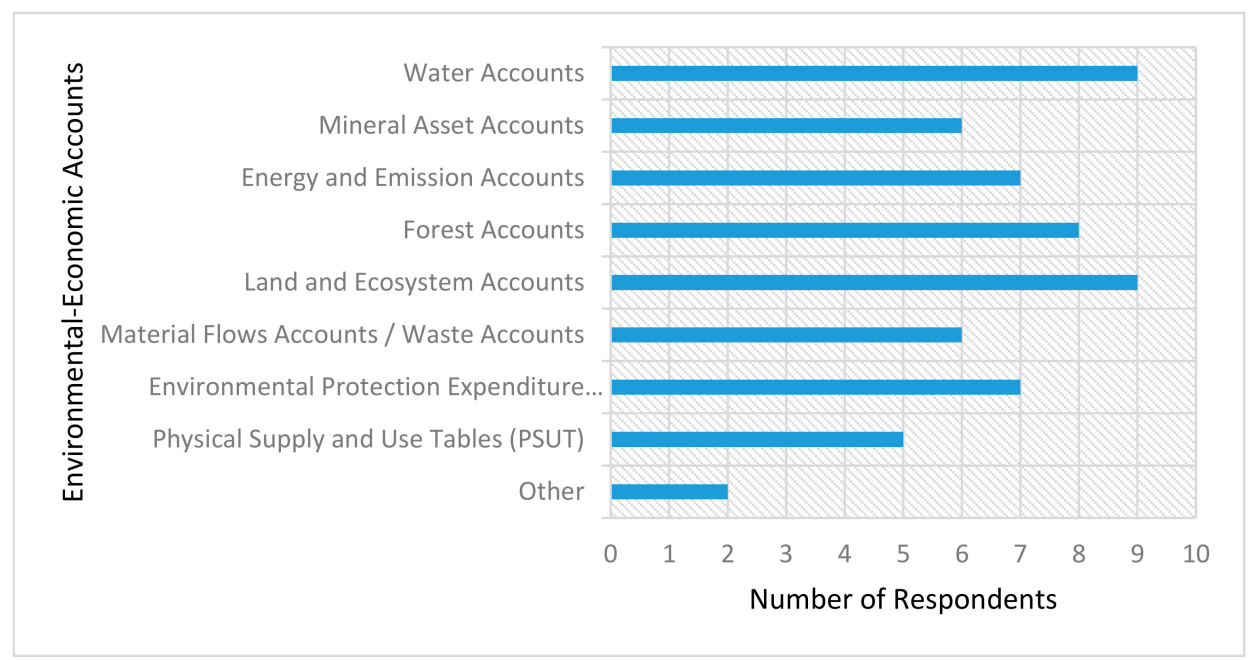

Figure 5. Plans to expand the compilation of environmental-economic accounts (source: own survey).

The Philippines and Indonesia plan to develop several new accounts. Supported by government funding and external funding from international organizations, The Philippines plans to develop water, mineral assets, forest, and land and ecosystem accounts, physical supply and use tables (PSUTs), and recreational accounts. Indonesia, a resource-rich country, plans to develop complete environmental-economic accounts to support policy formulation.

The survey results also indicated that the main limitation of environmental-economic accounts in supporting SDG monitoring indicators in developing countries was the lack of institutional setup and coordination (Figure 6).

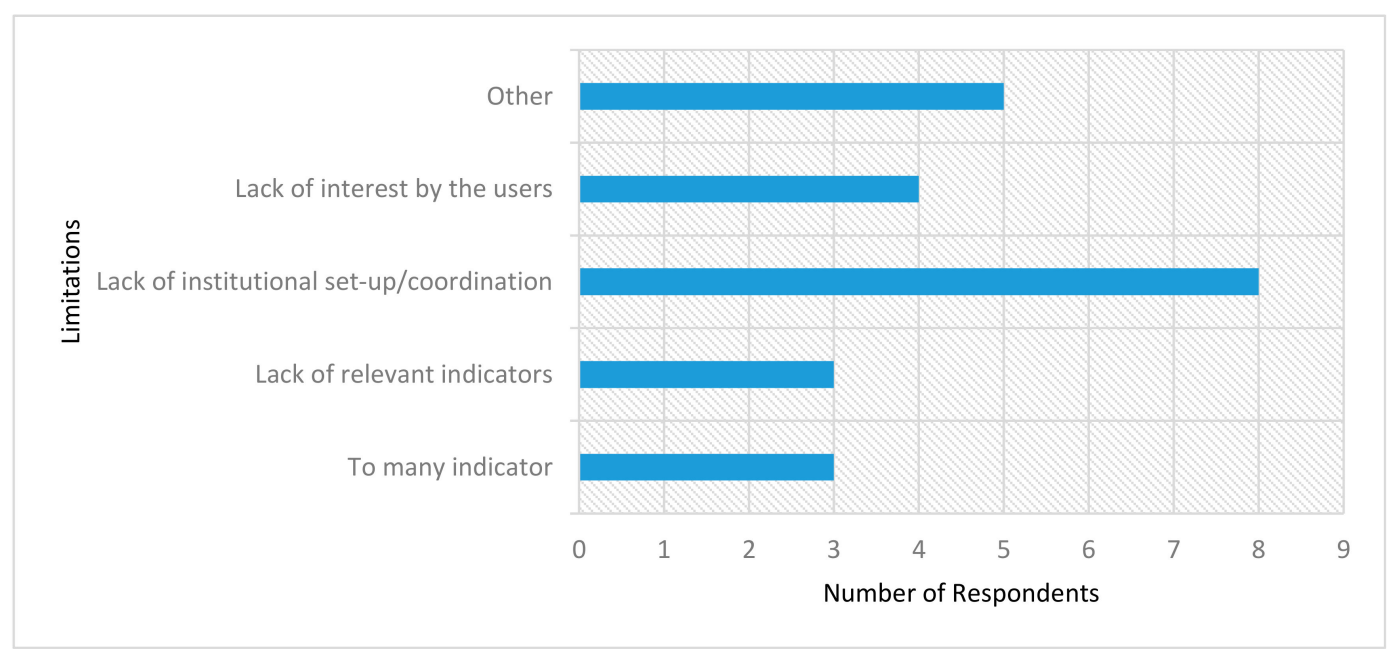

Figure 6. Limitations of comprehensive environmental-economic accounts in supporting SDG indicator monitoring (source: own survey). 


\subsection{Conclusions on the Implementation of SEEA}

Based on the literature review, international organization reports, and our own survey, we can draw some conclusions about SEEA implementation. The topics covered by environmental-economic accounting programs differ between developing and developed countries (mostly EU regions) [16-24]. In developing countries, existing activities and plans should be focused on the management of natural resources and specific security issues (e.g., energy security). Meanwhile, in developed countries, salient issues relate to expenditure flow, economic instruments, resource efficiency, and environmental degradation associated with economic production and consumption.

The WAVES program has proven the possibility of setting up environmental accounts in middle income countries, as well as its use in informing national development plans and policies.

Furthermore, our assessment survey indicated that regular funding and international organization assistance programs, such as WAVES, seem to affect the compilation and development of SEEA accounts positively, especially in developing countries, as previously described [16-21]. The survey also indicated that energy and water accounts are the most commonly compiled accounts in developing countries.

\section{Challenges in Implementing and Expanding of SEEA}

This section highlights the challenges in implementing and expanding SEEA accounting. This analysis is based on a literature survey and our surveys of experts in developing countries. The studies identified several challenges in compiling and developing SEEA accounts and will be essential for improving SEEA implementation, especially in developing countries.

\subsection{Implementation Challenges from the Literature and Survey}

Implementation barriers for the SEEA in developing countries are related to several issues. The UNSD 2007 Global Assessment asked respondents to identify the major constraints/impeding factors for the compilation of environmental-economic accounting (the UNSD 2014 Global Assessment did not include the question of impeding factors for their compilation of environmental-economic accounting). The Global Assessment noted that the top two impeding factors in the compilation of environmental-economic accounts are data availability and quality, especially in developing countries (Figure 7). This conclusion was reported previously [24] in the United Nations Economic and Social Commission for Asia and the Pacific (ESCAP) study for Pacific island nations.

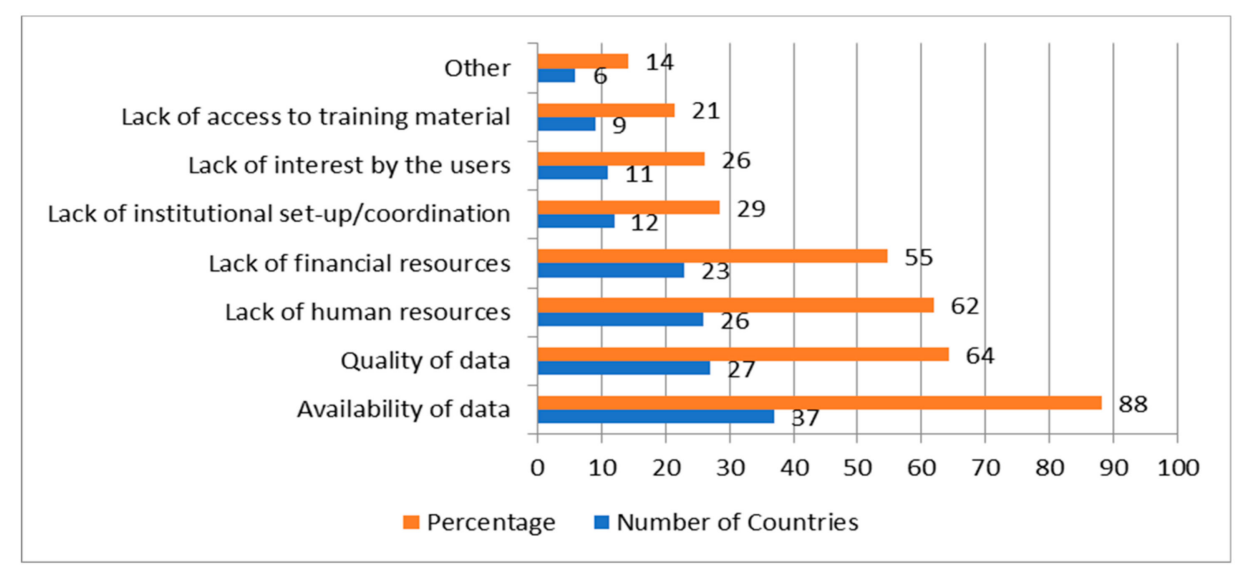

Figure 7. Impeding factors in the compilation of the environmental-economic accounting program (source: adapted from UNSD [16]).

These results are quite similar to those of our survey on the implementation of SEEA in several developing countries. In starting the compilation of the (current) environmental-economic accounts, the top three major constraints were data availability, data quality, and lack of human resources (Figure 8). 
The same three factors were the top three obstacles to further expanding an environmental-economic accounting program (Figure 9).

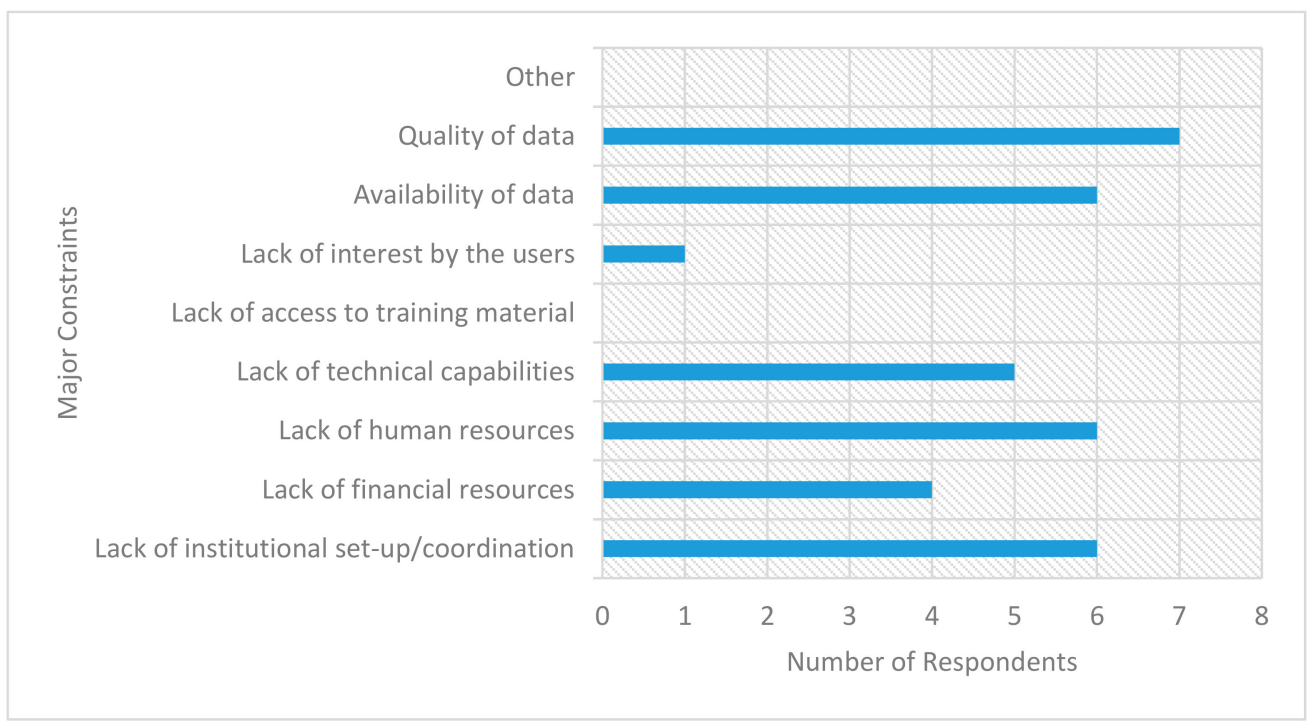

Figure 8. The major constraints in starting the compilation of the (current) environmental-economic accounts (source: own survey).

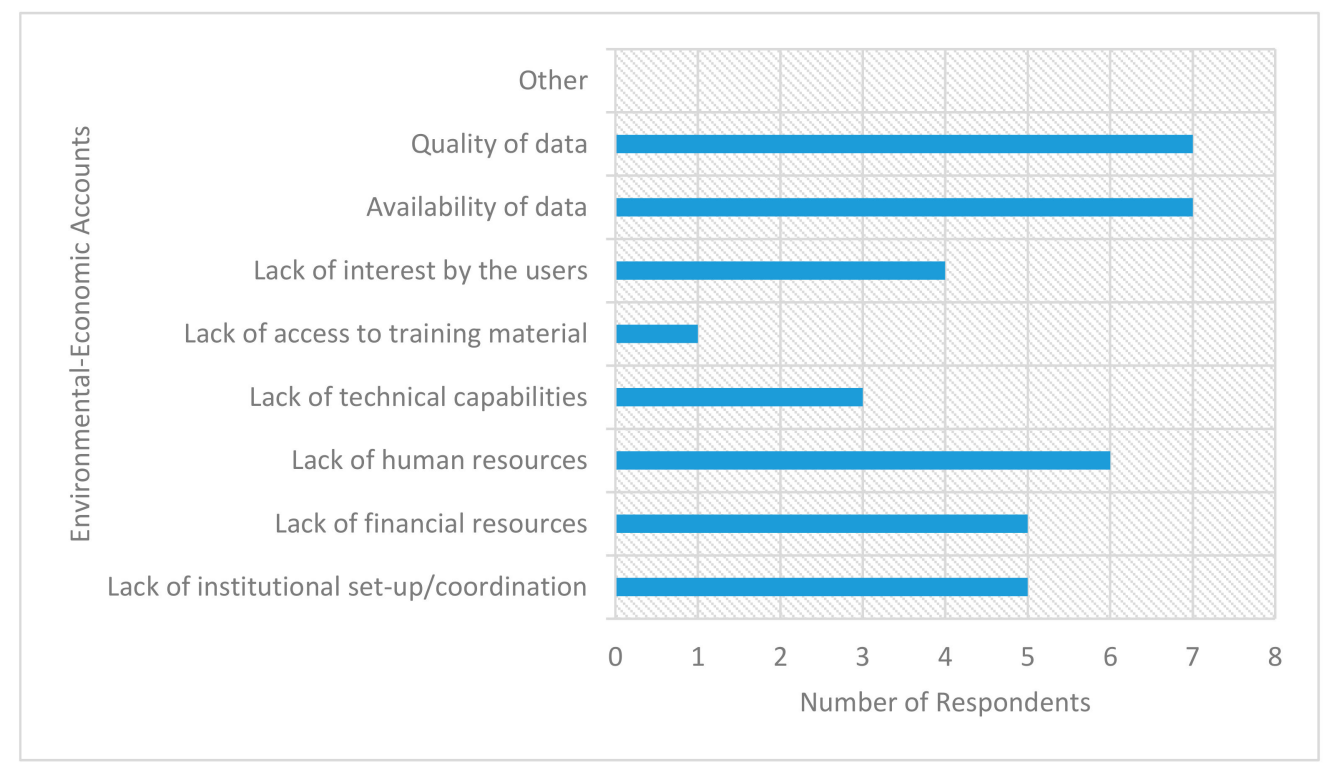

Figure 9. The major constraints for further expanding the environmental-economic accounting program (source: own survey).

\subsection{Potential Approaches to Addressing Implementation Challenges}

Barriers to the implementation of SEEA can be addressed in several ways. Our survey findings indicated that the responding countries with an SEEA program benefit from using training material, methodological guidelines, or country experiences, as well as technical assistance from international organizations in compiling environmental-economic accounts. For example, The Philippines experienced progress in developing and implementing the SEEA, supported by technical assistance from international organizations since the 1990s. From 1990 to 2012, this compilation was assisted by the UN and with USAID funded through the Environmental and Natural Resources Accounting Project (ENRAP); since 2013, the compilation has been assisted by the World Bank through the WAVES program. 
Further introduction and awareness of the potential usefulness of SEEA are required at the national level, especially by educating decision-makers [4]. As noted, Australia built its case for policy makers by educating them via its initial report, Completing the Picture: Environmental Accounting in Practice (ABS, 2012; in [4]). Moreover, the unsuccessful SEEA implementation in China confirms that a supportive state (governance) and political structures, leading agencies, collaborative entities, and the influence of decision-makers are instrumental for successful SEEA development and implementation [4].

Another important aspect that determines the success of SEEA implementation is the establishment of a multi-stakeholder mechanism to enable coordination in SEEA production and implementation. Financial and technical assistance from international agencies also plays a significant role, especially in developing countries. Our findings from the self-assessment survey indicated that regular funding from the government or an international agency is essential to support successful development and implementation. Countries without regular funding from their governments clearly experience greater obstacles in developing their SEEA accounts.

\subsection{Implication for SDG Monitoring}

The importance of the SEEA has grown in the last couple of decades. SEEA development is driven by a desire to present detailed and comprehensive information on the environment and to provide a better understanding of how it interacts with the economy. This study illustrated a strong relationship between SEEA and SDG indicators. The implementation of SDGs requires a solid framework of indicators and statistical data to inform policy-making, monitor progress, and ensure accountability. SEEA can meet this need by providing an internationally recognized, comparable, and consistent framework (including definitions, classifications, accounting concepts, and methods) for the accounting of natural capital (see the SEEA Brochure at https://unstats.un.org/unsd/envaccounting/Brochure.pdf).

Moreover, SEEA and SDGs are highly compatible, with a shared purpose and philosophy [13]. SDGs provide a policy framework, and the SEEA provides the necessary data to move towards sustainable development. SEEA, as an integrated statistical framework, can facilitate the production of statistics and indicators by national statistical systems, which are of enhanced quality, based on a set of criteria [11]: (i) policy relevance and utility; (ii) analytical and methodological soundness; and (iii) measurability and practicality.

The SEEA also can be implemented in countries at various stages of development by identifying data gaps and improving consistency. Through the WAVES program, the World Bank has shown that it is possible to produce accounts in middle income countries and inform national development plans and policies. Programs from international agencies can support countries in the compilation and implementation of SEEA via technical assistance, financial support, training materials, and methodological guidelines, thus improving the efficiency of the statistical output of basic data and other collaborative actions.

Realizing the full potential of the SEEA to support sustainable development and green policies (including supporting SDG implementation) requires cooperation and commitment at the national and international levels. Contributions from international agencies and donors are needed for SEEA implementation, including support from supporting institutions in middle income and low income countries to improve their capacity to establish high quality SEEA accounts and support SEEA implementation for their sustainable development policy agenda.

\section{Conclusions}

In this study, we provided a brief overview of the current and potential uses of SEEA to support SDG indicator monitoring. This study also included the results of a small assessment survey of the potential for SEEA to support this monitoring. From the literature review, we showed that SEEA is a potential tool that can help monitor SDG indicators and address priority issues in each country. The small assessment survey we conducted confirmed that almost all environmental-economic accounts have the potential to support SDG indicator monitoring. The surveys also showed that Goal 6, 
regarding the availability and sustainable management of water and sanitation for all, has the most potential to be supported by existing environmental-economic accounts, via water accounts, followed by Goals 7, 12, and 15. Moreover, the overall results from the survey confirmed the literature review analysis of the potential relationship between SEEA and SDG indicators.

Based on the literature review, we can draw some conclusions about the current SEEA implementation. The topics covered by environmental-economic accounting programs differ between developing and developed countries (mostly from EU regions). In developing countries, activities and plans should be understood from the perspective of requiring the management of natural resource endowments and specific security issues. Meanwhile, in developed countries, the most important issues are expenditure flow, economic instruments, resource efficiency, and environmental degradation related to economic production and consumption.

The results of the literature review and survey indicated that regular funding and programs such as WAVES positively affect the compilation and development of SEEA accounts, especially in developing countries. Furthermore, according to the survey results, energy and water accounts are the most commonly compiled accounts in developing countries. The survey also showed that data availability, data quality, and lack of human resources are the top three major constraints on starting the compilation of (current) environmental-economic accounts. Finally, the survey results also showed that the same three factors represent the top three obstacles to further expansion of an environmental-economic accounting program.

This study provided an overview and reflection on the possibilities of monitoring SDGs with SEEA, discussing limits and critical states and offering guidelines and recommendations. However, this study had some limitations in terms of our elaboration of the SEEA literature. In addition, we realize that the survey we conducted still had limitations, especially on the coverage of respondents. However, the survey, especially regarding the potential of the SEEA to support monitoring of SDG indicators, perhaps is the first attempt ever made. We hope this study will trigger the emergence of more comprehensive studies on the potential of the SEEA in supporting the success of the SDGs.

Author Contributions: Conceptualization, V.P., A.T., and R.H.; formal analysis, V.P.; investigation, V.P.; data curation, V.P.; writing—original draft preparation, V.P., writing-review and editing, V.P., A.T., A.S.A., and R.H.; supervision, A.T., A.S.A., and R.H.

Funding: This research was funded by the Indonesian Endowment Fund for Education (LPDP), grant number PRJ-1461/LPDP.3/2016, Ministry of Finance, Republic of Indonesia, as a part of the first author's doctoral scholarship at the Institute of Environmental Sciences (CML), Faculty of Science, Leiden University, Netherlands.

Acknowledgments: Viktor Pirmana acknowledges funding from the Indonesian Endowment Fund for Education (LPDP Scholarship), Ministry of Finance, Republic of Indonesia. Authors are also thankful for the valuable comments and suggestions made by the editor and reviewer team of The Sustainability Journal.

Conflicts of Interest: The authors declare no conflict of interest.

Appendix A. Questionnaire on Assessment of Environmental-Economic Accounting in Developing Countries

\section{Introductions}

This Assessment has the objectives of:

(a) Assessing the current status of national implementation of Environmental-Economic Accounting Programs in developing countries

(b) Assessing institutional arrangements for the compilation of Environmental-Economic Accounts in developing countries

(c) Identifying priorities and future plans for the compilation of Environmental-Economic Accounts

(d) Identifying the constraints in starting the compilation and developing Environmental-Economic Accounts 
(e) Identifying the role of WAVES program in compiling and developing Environmental-Economic Accounts

(f) Identifying the possibilities of Environmental-Economic Account to support the monitoring of SDG Indicators

You are kindly requested to complete the questionnaire for the country in which you operate. It would be appreciated if you could provide as much information as possible and submit any supporting documents when requested.

Please provide your contact information:

Country:

Name of Institution:

Contact person:

Position:

Email:

Tel:

1. Does country have a program on Environmental-Economic Accounting that is compiling data for, or developing SEEA-based accounting?

[ ] Yes

[ ] $\quad$ No $\rightarrow$ skip to question 18

2. If your country have a program on Environmental-Economic Accounting, is the program is a yearly/routine program?

[ ] Yes

[ ] No

3. After 2012, did the program already adopt SEEA-CF 2012 from UN?

[ ] Yes

[ ] No

4. Which modules of Environmental-Economic Accounting are compiled by your country?

[ ] Water Accounts

[ ] Mineral Asset Accounts

[ ] Energy and Emission Accounts

[ ] Forest Accounts

[ ] Land and Ecosystem Accounts

[ ] Material Flows Accounts/Waste Accounts

[ ] Environmental Protection Expenditure Accounts (EPEA)

[ ] Physical Supply and Use Tables (PSUT)

[ ] Other $\rightarrow$ Please specify (there is no limit in number of characters): environmental services 
5. In compiling Environmental-Economic Accounts, has your institution/agency made use of the following:

5a. Training material, methodological guidelines or country experiences?

[ ] Yes $\rightarrow$ Please specify (e.g. 1993 SNA, SEEA 2003, etc.):

[ ] No

5b. Technical assistance from international organizations or countries?

[ ] Yes $\rightarrow$ Please describe (e.g. during which period, nature of assistance, etc):

[ ] No

6. In compiling Environmental-Economic Accounts, your institution/agency funded by:

[ ] Government funding

[ ] External funding $\rightarrow$ Please specify (e.g. during which period, from which sources, etc):

7. In compiling Environmental-Economic Accounts, your institution/agency has regular funding?

[ ] Yes $\rightarrow$ Please specify (e.g. how many professional/supporting staff covered, ranges of funds, government or external sources, etc):

[ ] No

8. In compiling Environmental-Economic Accounts, is WAVES program has a significant role?

[ ] Yes $\rightarrow$ Please give a brief explanation:

[ ] No

9. Which modules/accounts is the most impacted by the existence of WAVES program?

[ ] Water Accounts

[ ] Mineral Asset Accounts

[ ] Energy and Emission Accounts

[ ] Forest Accounts

[ ] Land and Ecosystem Accounts

[ ] Material Flows Accounts/Waste Accounts

[ ] Environmental Protection Expenditure Accounts (EPEA)

[ ] Physical Supply and Use Tables (PSUT)

[ ] Other $\rightarrow$ Please specify (there is no limit in number of characters): environmental services

10. If the World Bank stops the WAVES Program, is your institution/agency will continue to compile the Environmental-Economic Accounts?

[ ] Yes

[ ] No

11. Are there plans to continue compiling the current Environmental-Economic Accounts in your institution/agency?

[ ] Yes

[ ] No 
12. Are there plans to expand the compilation of Environmental-Economic Accounts in your institution/agency?

[ ] Y Yes $\rightarrow$ Which modules?

[ ] Water Accounts

[ ] Mineral Asset Accounts

[ ] Energy and Emission Accounts

[ ] Forest Accounts

[ ] Land and Ecosystem Accounts

[ ] Material Flows Accounts/Waste Accounts

[ ] Environmental Protection Expenditure Accounts (EPEA)

[ ] Physical Supply and Use Tables (PSUT)

[ ] Other $\rightarrow$ Please specify (there is no limit in number of characters):

[ ] No

13. In relation with SDGs, do your institution/agency think that Environmental-Economic Accounting database is possible to support the SDG Indicators monitoring?

[ ] Yes $\rightarrow$ Please continue to the next questions

[ ] No $\rightarrow$ Skip to question 21

14. Which modules/accounts in your view can support SDG Indicators monitoring?

[ ] Water Accounts

[ ] Mineral Asset Accounts

[ ] Energy and Emission Accounts

[ ] Forest Accounts

[ ] Land and Ecosystem Accounts

[ ] Material Flows Accounts/Waste Accounts

[ ] Environmental Protection Expenditure Accounts (EPEA)

[ ] Physical Supply and Use Tables (PSUT)

[ ] Other $\rightarrow$ Please specify (there is no limit in number of characters): 
15. Which goal of SDGs in your view can support by the existence of the Environmental-Economic Accounts?

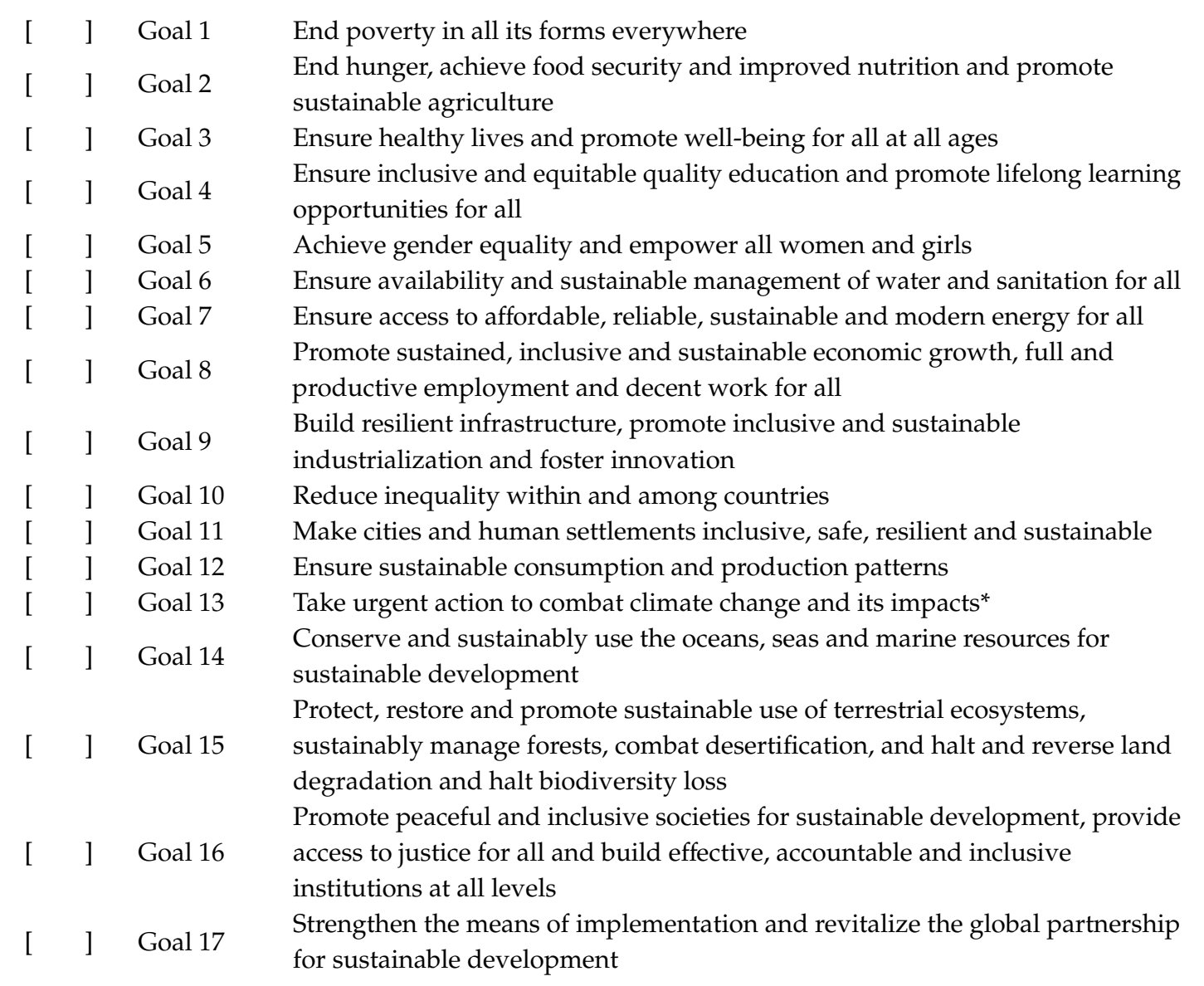


16. Which is the most potential goal of SDGs can support by Environmental-Economic Accounts?

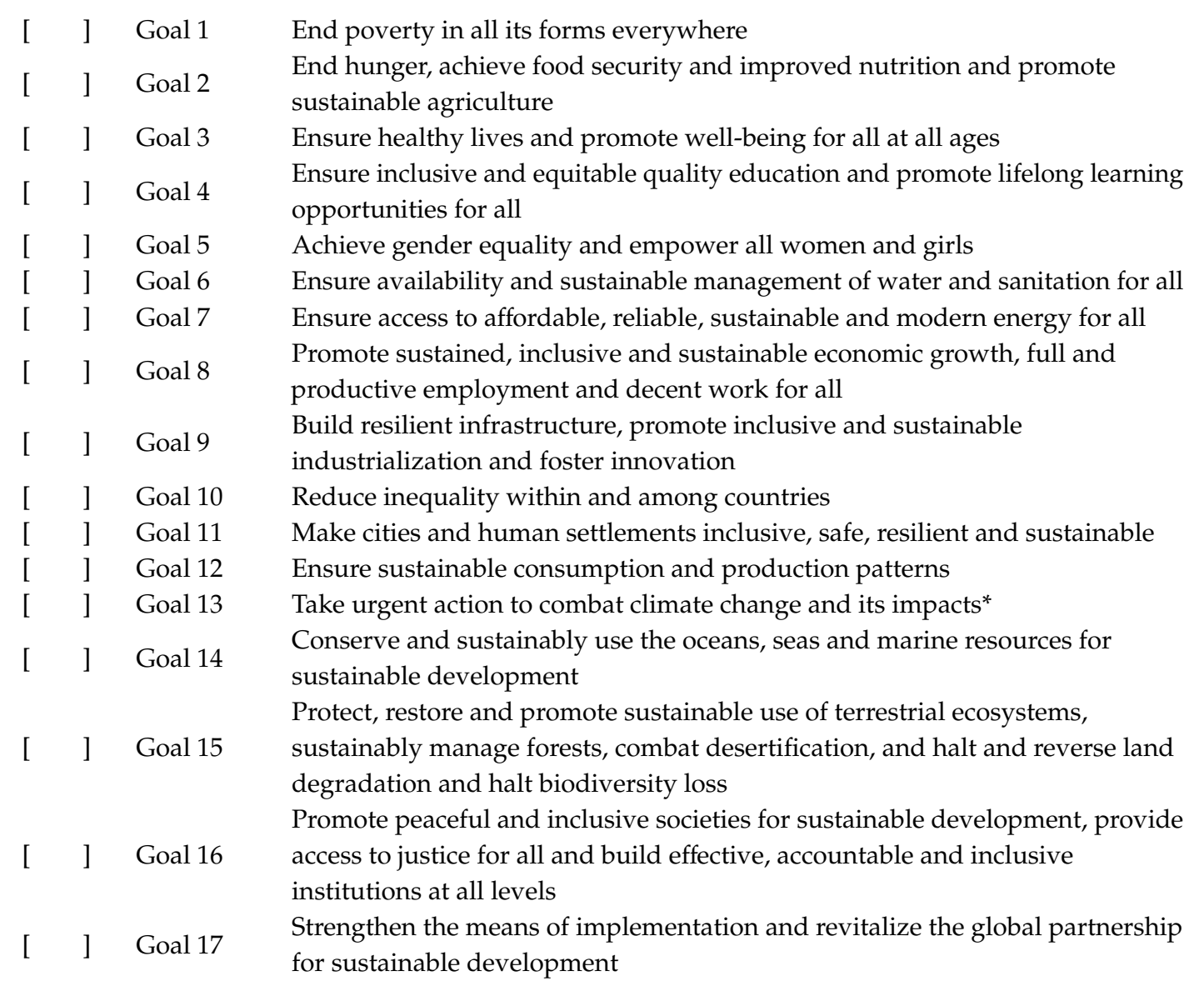

17.

What are the limitation of comprehensive Environmental-Economic Accounts to support SDG indicators monitoring?

[ ] To many indicator

[ ] Lack of relevant indicators

[ ] Lack of institutional set-up/coordination

[ ] Lack of interest by the users

[ ] Other $\rightarrow$ Please specify (there is no limit in number of characters):

What were the major constraints in starting the compilation of the (current) Environmental-Economic Accounts in your country? (Please check all that apply)

[ ] Lack of institutional set-up/coordination

[ ] Lack of financial resources

[ ] Lack of human resources

[ ] Lack of technical capabilities

[ ] Lack of access to training material

[ ] Lack of interest by the users

[ ] Availability of data

[ ] Quality of data 
[ ] Other $\rightarrow$ Please specify (there is no limit in number of characters):

19. What have been the major constraints further expanding the Environmental-Economic Accounting Program?

[ ] Lack of institutional set-up/coordination

[ ] Lack of financial resources

[ ] Lack of human resources

[ ] Lack of technical capabilities

[ ] Lack of access to training material

[ ] Lack of interest by the users

[ ] Availability of data

[ ] Quality of data

[ ] Other $\rightarrow$ Please specify (there is no limit in number of characters):

20.

Are there plans to compile any modules of the Environmental-Economic Accounts in your country in the near future?

[ ] Y Yes $\rightarrow$ Which modules?

[ ] Water Accounts

[ ] Mineral Asset Accounts

[ ] Energy and Emission Accounts

[ ] Forest Accounts

[ ] Land and Ecosystem Accounts

[ ] Material Flows Accounts/Waste Accounts

[ ] Environmental Protection Expenditure Accounts (EPEA)

[ ] Physical Supply and Use Tables (PSUT)

[ ] Other $\rightarrow$ Please specify (there is no limit in number of characters):

[ ] No

Please provide additional comments in the box below 


\section{Appendix B}

Table A1. List of Respondent Affiliation and Position.

\begin{tabular}{|c|c|c|c|}
\hline No. & Country & Affiliation & Position \\
\hline 1 & Columbia & $\begin{array}{l}\text { National Administrative Department } \\
\text { of Statistics (DANE) }\end{array}$ & $\begin{array}{l}\text { Coordinator Indicators and } \\
\text { Environmental Accounts }\end{array}$ \\
\hline 2 & Chile & Ministry of the Environment & $\begin{array}{l}\text { Manager-Unit of Environmental } \\
\text { Accounts and Indicators }\end{array}$ \\
\hline 3 & Brasil & $\begin{array}{c}\text { Instituto Brasileiro de Geografia e } \\
\text { Estatística }\end{array}$ & $\begin{array}{c}\text { técnico em informações geográficas e } \\
\text { estatística }\end{array}$ \\
\hline 4 & Curacao & Central Bureau of Statistics (CBS) & $\begin{array}{l}\text { Analyst, Head Business and } \\
\text { Environmental Statistics }\end{array}$ \\
\hline 5 & Guatemala & Universidad Rafael Landívar/IARNA & $\begin{array}{l}\text { Academic research associate/Sr. } \\
\text { Environmental Economist WAVES }\end{array}$ \\
\hline 6 & Costa Rica & Banco Central de Costa Rica (BCCR) & $\begin{array}{l}\text { Coordinator of Environmental } \\
\text { Statistics Unit }\end{array}$ \\
\hline 7 & Bangladesh & Bangladesh Bureau of Statistics (BBS) & Deputy Director \\
\hline 8 & Philipines & $\begin{array}{l}\text { Resources, Environment and } \\
\text { Economics Center for Studies }\end{array}$ & President/ Resoure Economict \\
\hline 9 & Indonesia & Central Bureau of Statistics (CBS) & $\begin{array}{c}\text { Head of Sub-directorate on Regional } \\
\text { Production Account }\end{array}$ \\
\hline 10 & Iran & Statistical Centre of Iran & $\begin{array}{l}\text { Director General, Office of the Head, } \\
\text { Public Relations and International } \\
\text { cooperation }\end{array}$ \\
\hline 11 & Fiji & Fiji Bureau of Statistics & Government statistician \\
\hline 12 & South Africa & Statistics South Africa & $\begin{array}{l}\text { Deputy Director: Application of } \\
\text { National Accounts }\end{array}$ \\
\hline 13 & Botswana & $\begin{array}{c}\text { Ministry of Finance \& economic } \\
\text { Development }\end{array}$ & $\begin{array}{l}\text { Chief Economist/Coordinator of } \\
\text { WAVES Program for Botswana }\end{array}$ \\
\hline 14 & Jamaica & $\begin{array}{c}\text { Science and Technology Development } \\
\text { Planner/SIDS }\end{array}$ & $\begin{array}{l}\text { Dock National Coordinator Planning } \\
\text { Institute of Jamaica (PIOJ) }\end{array}$ \\
\hline
\end{tabular}




\section{Appendix C}

Table A2. Possible SDG Indicators that can be constructed from SEEA databases.

\begin{tabular}{|c|c|c|c|c|}
\hline Goals and Targets & Indicators & Account & Type of Account & Tier \\
\hline \multicolumn{5}{|c|}{ Goal 2. End hunger, achieve food security and improved nutrition and promote sustainable agriculture } \\
\hline $\begin{array}{l}2.3 \text { By 2030, double the agricultural } \\
\text { productivity and incomes of } \\
\text { small-scale food producers, in } \\
\text { particular women, indigenous } \\
\text { peoples, family farmers, pastoralists } \\
\text { and fishers, including through secure } \\
\text { and equal access to land, other } \\
\text { productive resources and inputs, } \\
\text { knowledge, financial services, } \\
\text { markets and opportunities for value } \\
\text { addition and non-farm employment }\end{array}$ & $\begin{array}{l}\text { 2.3.1 Volume of production } \\
\text { per labour unit by classes of } \\
\text { farming/pastoral/forestry } \\
\text { enterprise size }\end{array}$ & $\begin{array}{l}\text { Agriculture, } \\
\text { Forestry and } \\
\text { Fisheries }\end{array}$ & All & Tier II \\
\hline $\begin{array}{l}2.4 \text { By } 2030 \text {, ensure sustainable food } \\
\text { production systems and implement } \\
\text { resilient agricultural practices that } \\
\text { increase productivity and production, } \\
\text { that help maintain ecosystems, that } \\
\text { strengthen capacity for adaptation to } \\
\text { climate change, extreme weather, } \\
\text { drought, flooding and other disasters } \\
\text { and that progressively improve land } \\
\text { and soil quality }\end{array}$ & $\begin{array}{l}\text { 2.4.1 Proportion of } \\
\text { agricultural area under } \\
\text { productive and sustainable } \\
\text { agriculture }\end{array}$ & $\begin{array}{l}\text { Land }+ \text { Agriculture, } \\
\text { Forestry and } \\
\text { Fisheries }\end{array}$ & Asset accounts & Tier II \\
\hline $\begin{array}{l}\text { 2.a Increase investment, including } \\
\text { through enhanced international } \\
\text { cooperation, in rural infrastructure, } \\
\text { agricultural research and extension } \\
\text { services, technology development } \\
\text { and plant and livestock gene banks in } \\
\text { order to enhance agricultural } \\
\text { productive capacity in developing } \\
\text { countries, in particular least } \\
\text { developed countries }\end{array}$ & $\begin{array}{l}\text { 2.a.1 The agriculture } \\
\text { orientation index for } \\
\text { government expenditures }\end{array}$ & $\begin{array}{l}\text { SNA + } \\
\text { Environmental } \\
\text { activities }\end{array}$ & All & Tier I \\
\hline \multicolumn{5}{|c|}{ Goal 6. Ensure availability and sustainable management of water and sanitation for all } \\
\hline $\begin{array}{l}6.1 \text { By } 2030 \text {, achieve universal and } \\
\text { equitable access to safe and affordable } \\
\text { drinking water for all }\end{array}$ & $\begin{array}{l}\text { 6.1.1 Proportion of } \\
\text { population using safely } \\
\text { managed drinking water } \\
\text { services }\end{array}$ & Water & $\begin{array}{l}\text { PSUT }+ \\
\text { Economic } \\
\text { Accounts }\end{array}$ & Tier II \\
\hline $\begin{array}{l}6.2 \text { By } 2030 \text {, achieve access to } \\
\text { adequate and equitable sanitation and } \\
\text { hygiene for all and end open } \\
\text { defecation, paying special attention to } \\
\text { the needs of women and girls and } \\
\text { those in vulnerable situations }\end{array}$ & $\begin{array}{l}\text { 6.2.1 Proportion of } \\
\text { population using safely } \\
\text { managed sanitation services, } \\
\text { including a hand-washing } \\
\text { facility with soap and water }\end{array}$ & Water & $\begin{array}{l}\text { PSUT + } \\
\text { Economic } \\
\text { Accounts }\end{array}$ & Tier II \\
\hline \multirow{2}{*}{$\begin{array}{l}6.3 \text { By } 2030 \text {, improve water quality by } \\
\text { reducing pollution, eliminating } \\
\text { dumping and minimizing release of } \\
\text { hazardous chemicals and materials, } \\
\text { halving the proportion of untreated } \\
\text { wastewater and substantially } \\
\text { increasing recycling and safe reuse } \\
\text { globally }\end{array}$} & $\begin{array}{l}\text { 6.3.1 Proportion of } \\
\text { wastewater safely treated }\end{array}$ & Water & PSUT & Tier II \\
\hline & $\begin{array}{l}\text { 6.3.2 Proportion of bodies of } \\
\text { water with good ambient } \\
\text { water quality }\end{array}$ & Materials & $\begin{array}{l}\text { Emmission } \\
\text { Accounts }\end{array}$ & Tier II \\
\hline
\end{tabular}


Table A2. Cont.

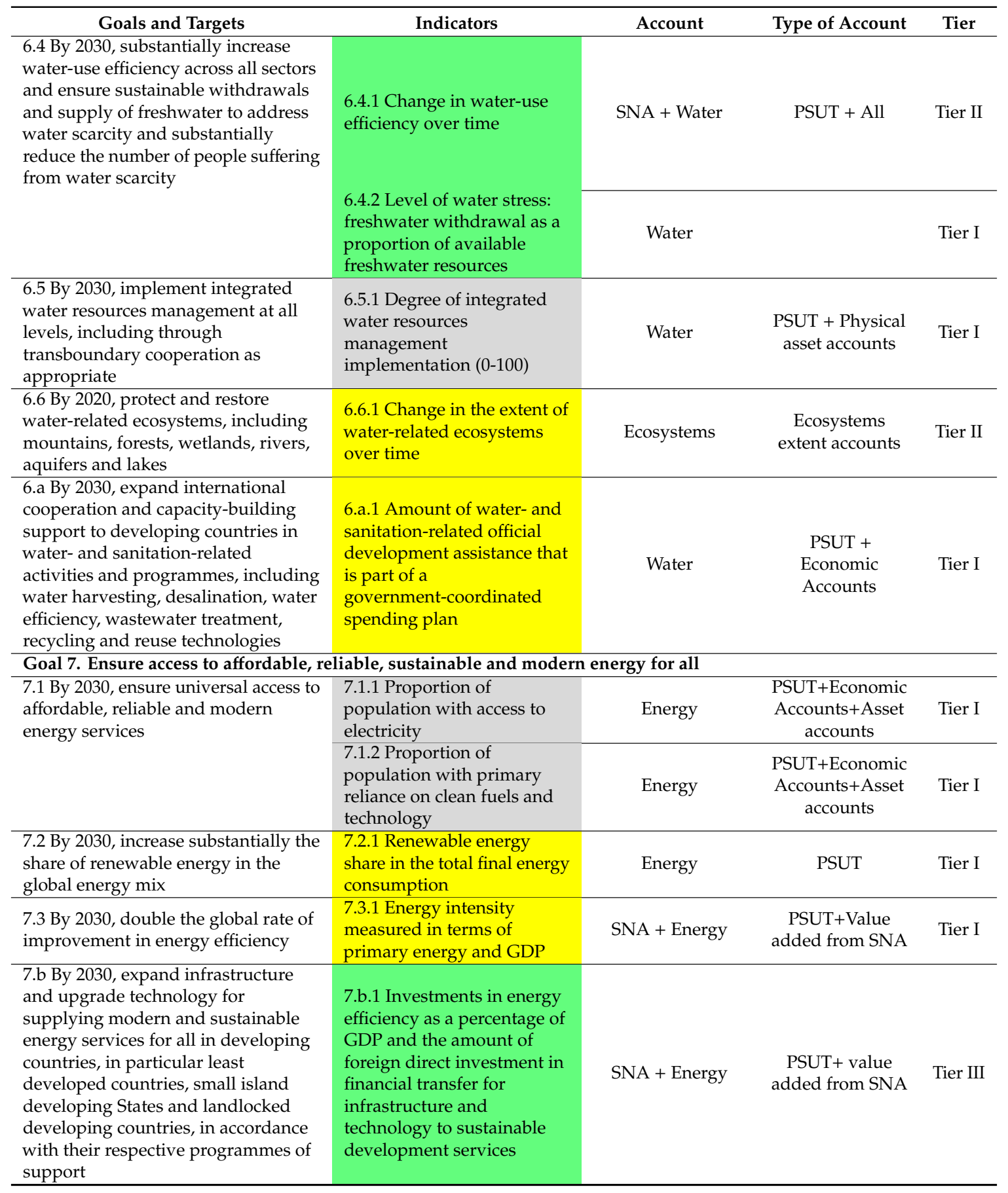


Table A2. Cont.

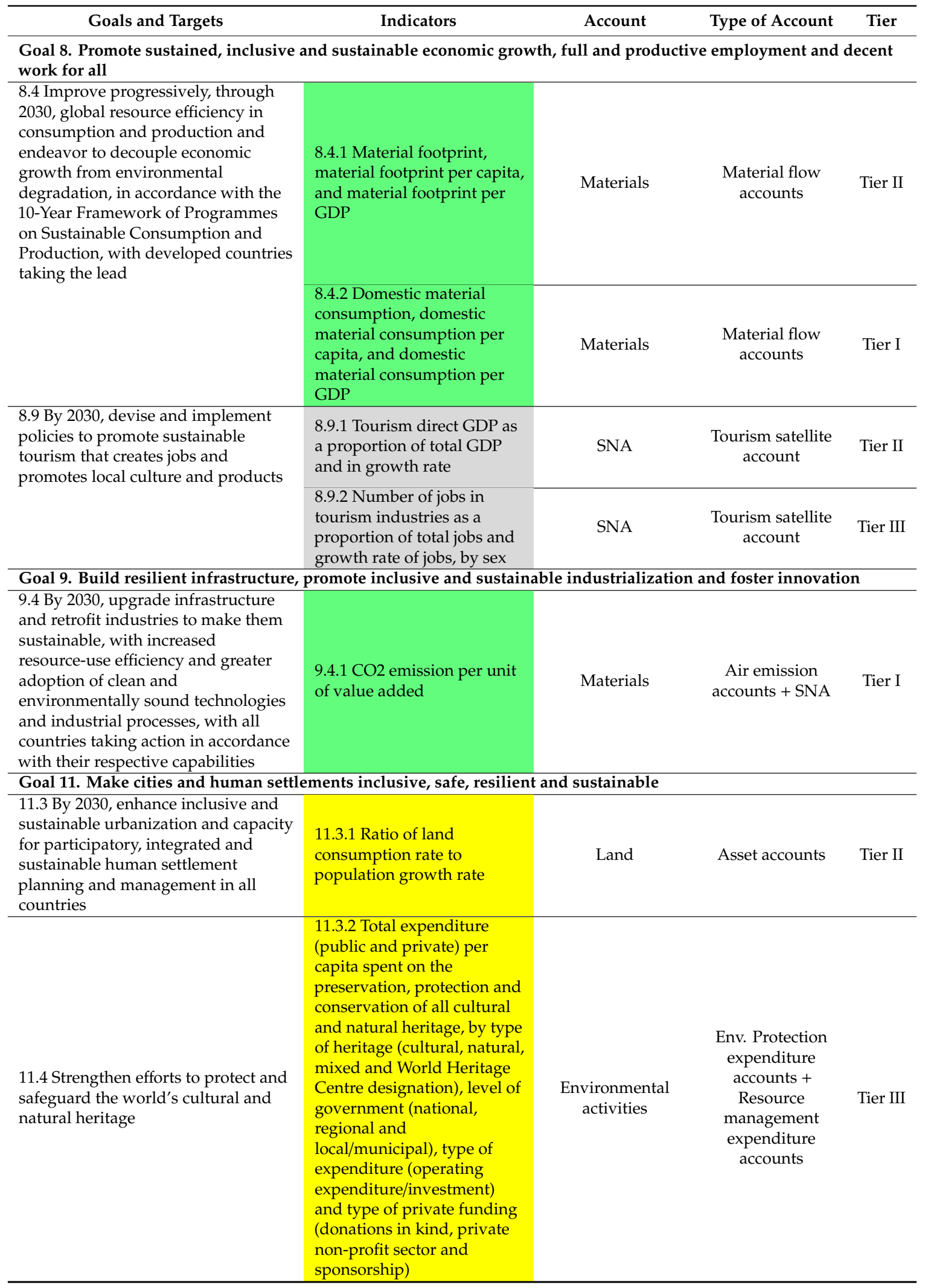


Table A2. Cont.

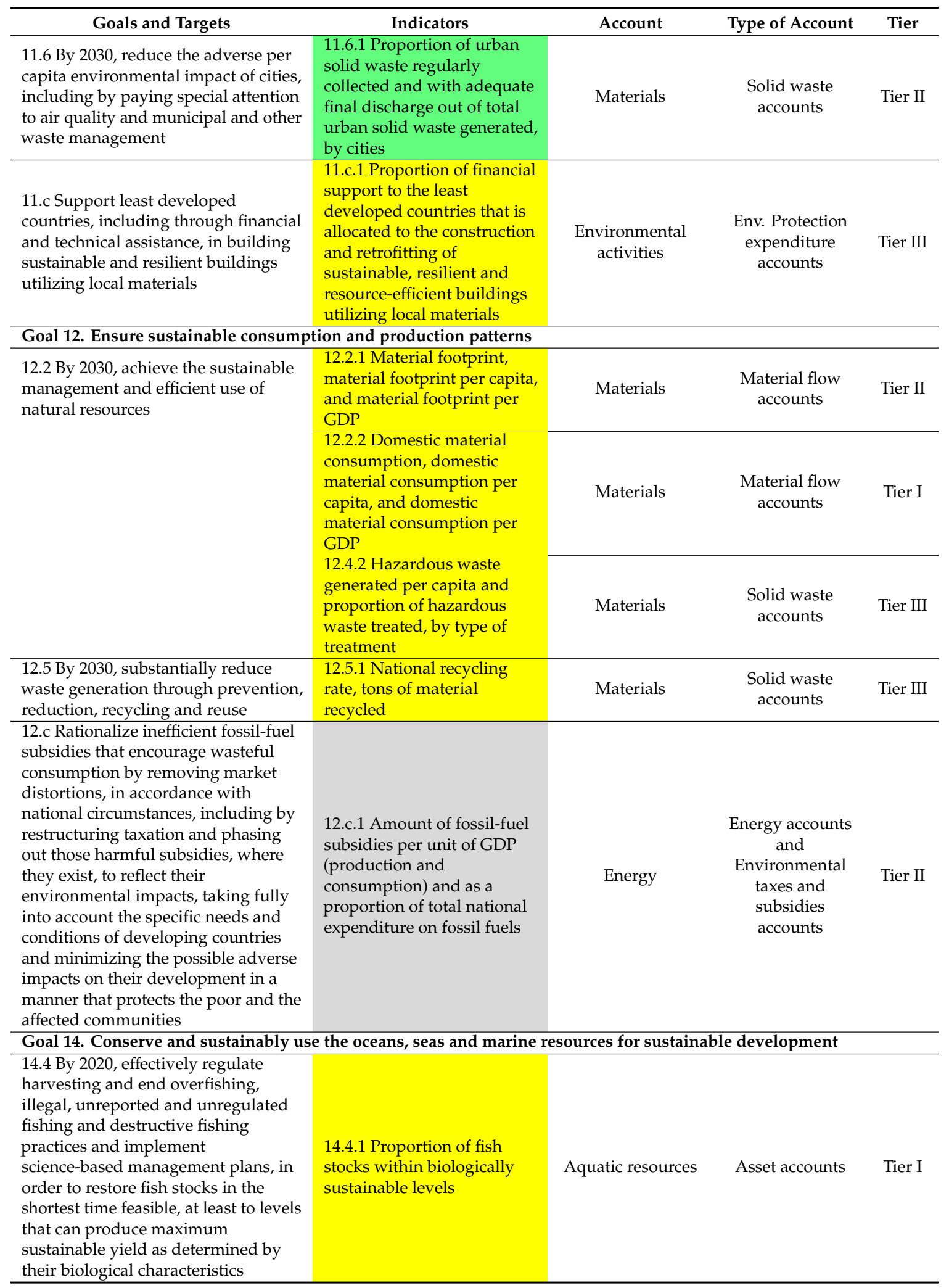


Table A2. Cont.

\begin{tabular}{|c|c|c|c|c|}
\hline Goals and Targets & Indicators & Account & Type of Account & Tier \\
\hline $\begin{array}{l}14.5 \text { By } 2020 \text {, conserve at least } 10 \text { per } \\
\text { cent of coastal and marine areas, } \\
\text { consistent with national and } \\
\text { international law and based on the } \\
\text { best available scientific information }\end{array}$ & $\begin{array}{l}14.5 .1 \text { Coverage of protected } \\
\text { areas in relation to marine } \\
\text { areas }\end{array}$ & Land & Asset accounts & Tier I \\
\hline $\begin{array}{l}14.7 \text { By } 2030 \text {, increase the economic } \\
\text { benefits to small island developing } \\
\text { States and least developed countries } \\
\text { from the sustainable use of marine } \\
\text { resources, including through } \\
\text { sustainable management of fisheries, } \\
\text { aquaculture and tourism }\end{array}$ & $\begin{array}{l}\text { 14.7.1 Sustainable fisheries } \\
\text { as a percentage of GDP in } \\
\text { small island developing } \\
\text { States, least developed } \\
\text { countries and all countries }\end{array}$ & $\begin{array}{l}\text { Agriculture, } \\
\text { Forestry and } \\
\text { Fisheries }\end{array}$ & All & Tier I \\
\hline $\begin{array}{l}\text { 14.a Increase scientific knowledge, } \\
\text { develop research capacity and } \\
\text { transfer marine technology, taking } \\
\text { into account the Intergovernmental } \\
\text { Oceanographic Commission Criteria } \\
\text { and Guidelines on the Transfer of } \\
\text { Marine Technology, in order to } \\
\text { improve ocean health and to enhance } \\
\text { the contribution of marine } \\
\text { biodiversity to the development of } \\
\text { developing countries, in particular } \\
\text { small island developing States and } \\
\text { least developed countries }\end{array}$ & $\begin{array}{l}\text { 14.a.1 Proportion of total } \\
\text { research budget allocated to } \\
\text { research in the field of } \\
\text { marine technology }\end{array}$ & $\begin{array}{l}\text { Environmental } \\
\text { activities }\end{array}$ & $\begin{array}{l}\text { Env. Protection } \\
\text { expenditure } \\
\text { accounts }\end{array}$ & Tier II \\
\hline \multicolumn{5}{|c|}{$\begin{array}{l}\text { Goal 15. Protect, restore and promote sustainable use of terrestrial ecosystems, sustainably manage forests, combat } \\
\text { desertification, and halt and reverse land degradation and halt biodiversity loss }\end{array}$} \\
\hline \multirow{2}{*}{$\begin{array}{l}15.1 \text { By } 2020 \text {, ensure the conservation, } \\
\text { restoration and sustainable use of } \\
\text { terrestrial and inland freshwater } \\
\text { ecosystems and their services, in } \\
\text { particular forests, wetlands, } \\
\text { mountains and drylands, in line with } \\
\text { obligations under international } \\
\text { agreements }\end{array}$} & $\begin{array}{l}\text { 15.1.1 Forest area as a } \\
\text { proportion of total land area }\end{array}$ & Land & Asset accounts & Tier I \\
\hline & $\begin{array}{l}\text { 15.1.2 Proportion of } \\
\text { important sites for terrestrial } \\
\text { and freshwater biodiversity } \\
\text { that are covered by protected } \\
\text { areas, by ecosystem type }\end{array}$ & Land & Asset accounts & Tier I \\
\hline $\begin{array}{l}15.3 \text { By } 2030, \text { combat desertification, } \\
\text { restore degraded land and soil, } \\
\text { including land affected by } \\
\text { desertification, drought and floods, } \\
\text { and strive to achieve a land } \\
\text { degradation-neutral world }\end{array}$ & $\begin{array}{l}\text { 15.1.3 Proportion of land } \\
\text { that is degraded over total } \\
\text { land area }\end{array}$ & Ecosystems & $\begin{array}{l}\text { Condition } \\
\text { accounts }\end{array}$ & Tier II \\
\hline \multirow{2}{*}{$\begin{array}{l}15.4 \text { By } 2030 \text {, ensure the conservation } \\
\text { of mountain ecosystems, including } \\
\text { their biodiversity, in order to enhance } \\
\text { their capacity to provide benefits that } \\
\text { are essential for sustainable } \\
\text { development }\end{array}$} & $\begin{array}{l}\text { 15.4.1 Coverage by protected } \\
\text { areas of important sites for } \\
\text { mountain biodiversity }\end{array}$ & Land & Asset accounts & Tier I \\
\hline & $\begin{array}{l}\text { 15.4.2 Mountain Green } \\
\text { Cover Index }\end{array}$ & Land & Asset accounts & Tier I \\
\hline $\begin{array}{l}15.5 \text { Take urgent and significant action } \\
\text { to reduce the degradation of natural } \\
\text { habitats, halt the loss of biodiversity } \\
\text { and, by } 2020 \text {, protect and prevent the } \\
\text { extinction of threatened species }\end{array}$ & 15.5.1 Red List Index & Ecosystems & $\begin{array}{l}\text { Biodiversity } \\
\text { accounts }\end{array}$ & Tier I \\
\hline
\end{tabular}


Table A2. Cont.

\begin{tabular}{|c|c|c|c|c|}
\hline Goals and Targets & Indicators & Account & Type of Account & Tier \\
\hline $\begin{array}{l}\text { 15.a Mobilize and significantly } \\
\text { increase financial resources from all } \\
\text { sources to conserve and sustainably } \\
\text { use biodiversity and ecosystems }\end{array}$ & $\begin{array}{l}\text { 15.a.1 Official development } \\
\text { assistance and public } \\
\text { expenditure on conservation } \\
\text { and sustainable use of } \\
\text { biodiversity and ecosystems }\end{array}$ & $\begin{array}{c}\text { Environmental } \\
\text { activities }\end{array}$ & $\begin{array}{l}\text { Env. Protection } \\
\text { expenditure } \\
\text { accounts }\end{array}$ & $\begin{array}{l}\text { Tier } \\
\text { I/III }\end{array}$ \\
\hline $\begin{array}{l}\text { 15.b Mobilize significant resources } \\
\text { from all sources and at all levels to } \\
\text { finance sustainable forest } \\
\text { management and provide adequate } \\
\text { incentives to developing countries to } \\
\text { advance such management, including } \\
\text { for conservation and reforestation }\end{array}$ & $\begin{array}{l}\text { 15.b.1 Official development } \\
\text { assistance and public } \\
\text { expenditure on conservation } \\
\text { and sustainable use of } \\
\text { biodiversity and ecosystems }\end{array}$ & $\begin{array}{c}\text { Environmental } \\
\text { activities }\end{array}$ & $\begin{array}{l}\text { Env. Protection } \\
\text { expenditure } \\
\text { accounts }\end{array}$ & $\begin{array}{l}\text { Tier } \\
\text { I/III }\end{array}$ \\
\hline \multicolumn{5}{|c|}{ Goal 17. Strengthen the means of implementation and revitalize the Global Partnership for Sustainable Development } \\
\hline
\end{tabular}

Source: Updated and modified from: UNCEEA (2016), "Broad brush analysis of SEEA relevant SDG indicators". http://unstats.un.org/unsd/envaccounting/ceea/documents/Broad\%20Brush_7\%20September.xlsx. Notes: PSUT: Physical Supply and Use Table; Broad brush analysis from UNCEEA (2016) and Ruinj et.al (2018) compared with the list of global SDG indicators as approved by UNSC in March 2016. This study use the suggested indicator and Definition updated using the latest version of Revised list of global Sustainable Development Goal indicators (March, 2017), retrieved from https://unstats.un.org/sdgs/indicators/Official\%20Revised $\% 20$ List $\% 20$ of $\% 20$ global\% 20SDG\%20indicators.pdf (accessed on 11 May 2019); This Broad brush analysis is updated and completed with Tier Classification for Global SDG Indicators from United Nation Statistical Division (UNSD) https://unstats.un.org/sdgs/ files/Tier_Classification_of_SDG_Indicators_22_May_2019_web.xlsx (accessed on 19 August 2019).

\section{Defining 'SEEA Relevant':}

: Indicator as currently proposed can be informed by the SEEA Accounts

: Either current wording and concepts of indicator needs to be aligned to be SEEA compliant; or indicator needs to be further defined to ensure SEEA compliance (i.e., detailed definitions added)

: While the indicator cannot be informed by the SEEA, either; a) the SEEA can provide important contextual information and the indicator should be developed with the SEEA approach in mind; or b) there is some overlap with SEEA methodology which should be considered when formulating this indicator. 


\section{Appendix D}

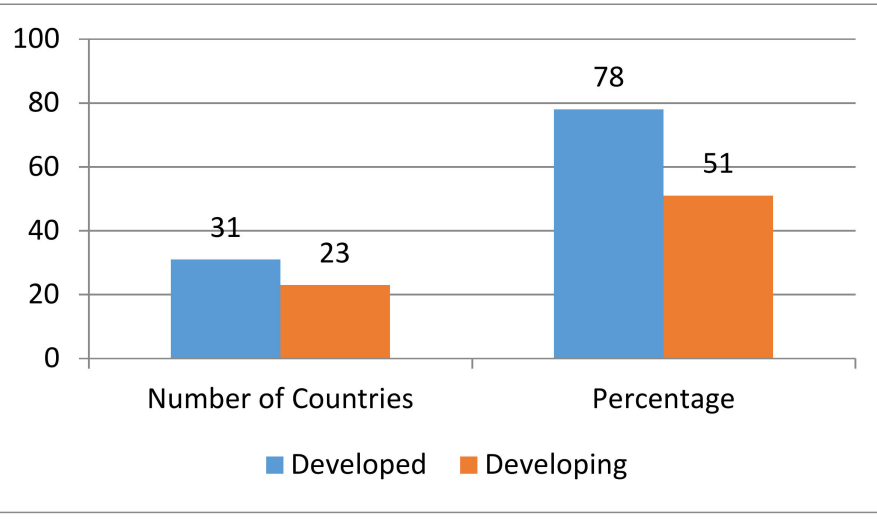

(a). Number of Countries, by Economic Grouping

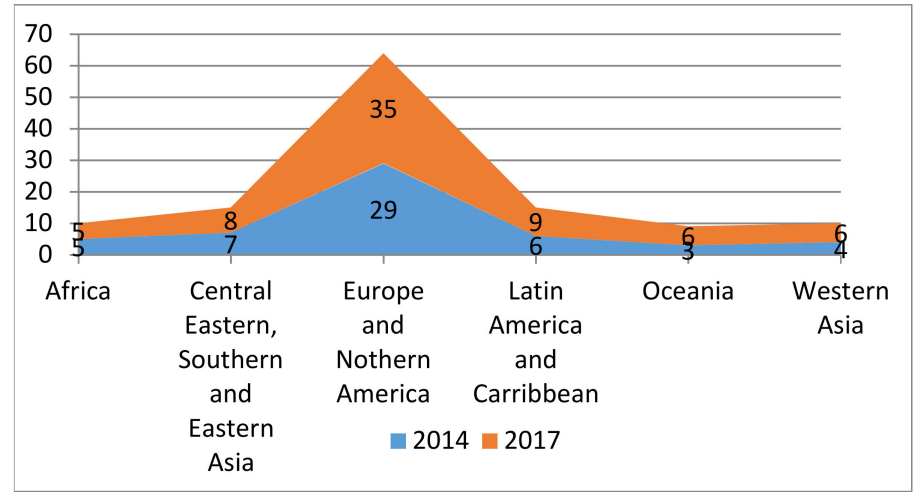

(c). Number of Countries, by Geographical Grouping

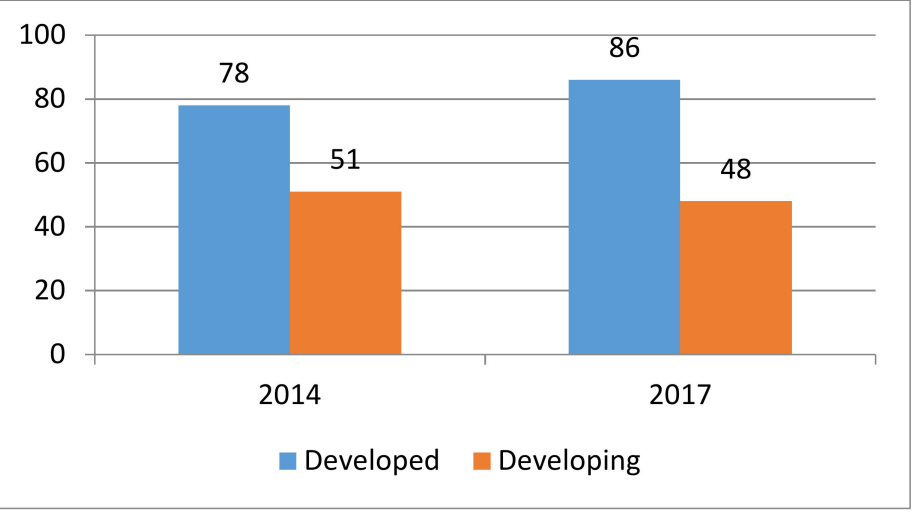

(b). Percentage of Countries, by Economic Grouping

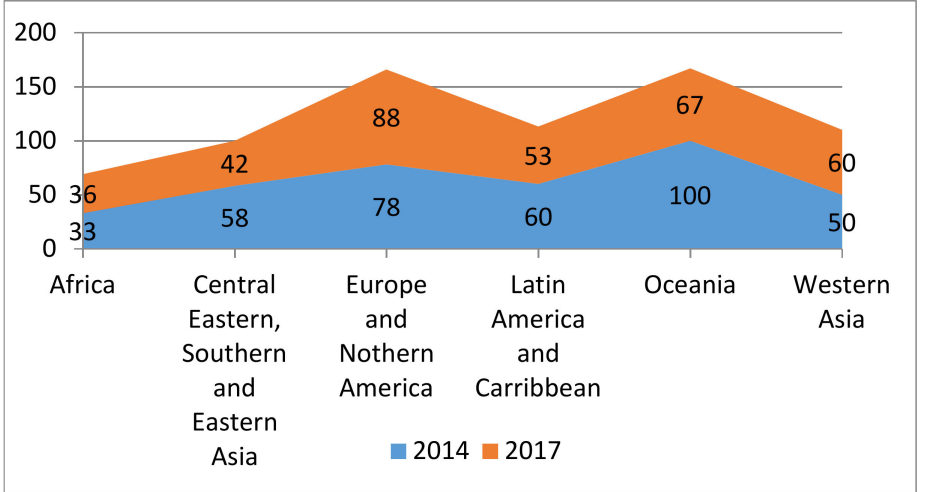

(d). Percentage of Countries, by Geographical Grouping

Figure A1. Existence of Environmental-Economic Accounting Program in Countries (Adapted from: UNSD, 2015 and UNSD 2018). 


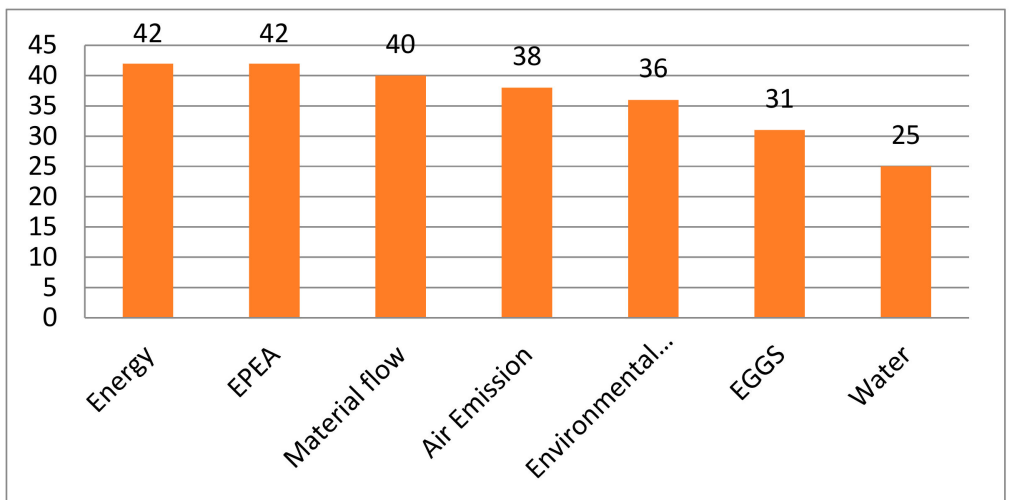

(a). All Countries, 2014

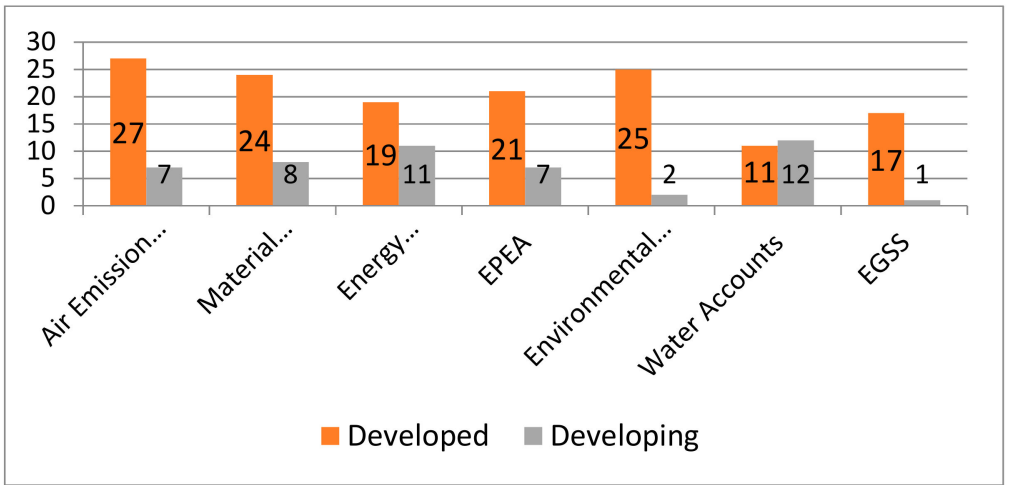

(c). Economic Regions, 2014

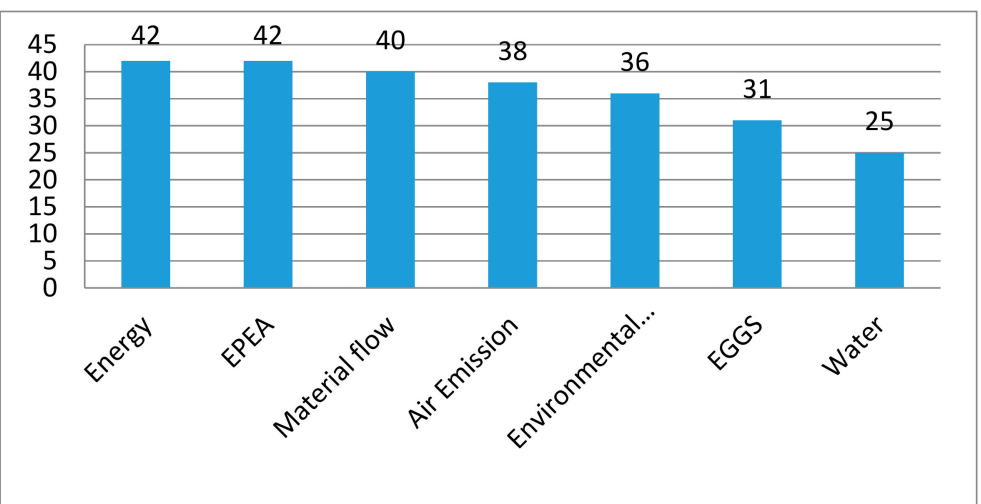

(b). All Countries, 2017

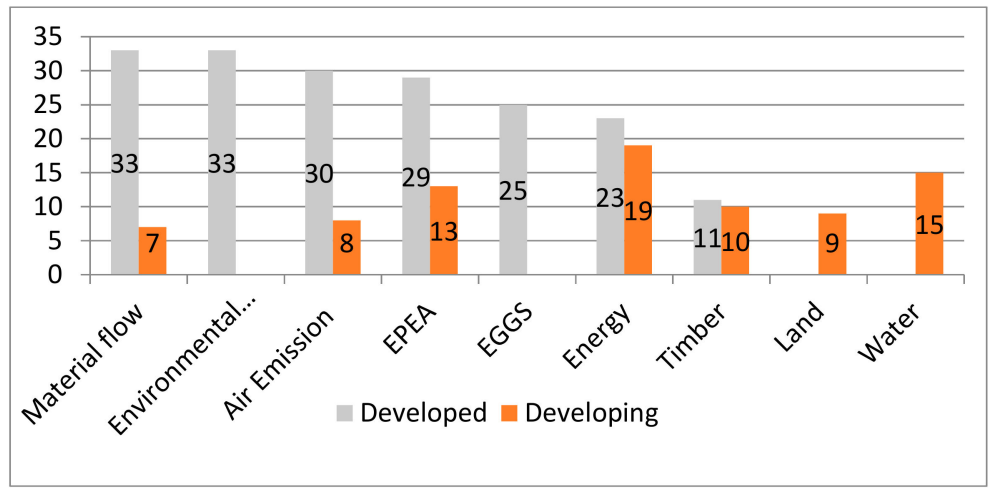

(d). Economic Regions, 2017

Figure A2. Modules/Accounts Covered in Environmental-Economic Accounting Program by Economic Region (Adapted from: UNSD, 2015 and UNSD 2018). 


\section{References}

1. Alisjahbana, A.S.; Murniningtyas, E. Tujuan Pembangunan Berkelanjutan di Indonesia: Konsep, Target dan Strategi Implementasi; UNPAD Press: West Java, Indonesia, 2018.

2. Nicolai, S.; Hoy, C.; Berliner, T.; Aedy, T. Projecting Progress: Reaching the SDGs by 2030. In Development Progress Research Report; ODI: London, UK, 2015.

3. Sachs, J.; Schmidt-Traub, G.; Kroll, C.; Durand-Delacre, D.; Teksoz, K. SDG Index and Dashboards Report 2017; Bertelsmann Stiftung and Sustainable Development Solutions Network (SDSN): New York, NY, USA, 2017.

4. March, R. Greening GDP: Overcoming Challenges in Natural Capital Accounting. Ph.D. Thesis, Bard College, Dutchess, NY, USA, May 2015.

5. Alfsen, K.H.; Greaker, M. From natural resources and environmental accounting to construction of indicators for sustainable development. Ecol. Econ. 2007, 61, 600-610. [CrossRef]

6. United Nations Statistics Division (UNSD). SDG Indicators Metadata; UNSD: New York, NY, USA, 2017.

7. Smith, R. Development of the SEEA 2003 and its implementation. Ecol. Econ. 2007, 61, 592-599. [CrossRef]

8. Palm, V.; Larsson, M. Economic instruments and the environmental accounts. Ecol. Econ. 2007, 61, 684-692. [CrossRef]

9. Nahman, A.; Mahumani, B.K.; de Lange, W.J. Beyond GDP: Towards a Green Economy Index. Dev. South. Afr. 2016, 3, 215-233. [CrossRef]

10. United Nation. System of Environmental Economic Accounting. 2016. Available online: http://unstats.un.org/ unsd/envaccounting/seea.asp (accessed on 4 November 2018).

11. United Nations Statistics Division (UNSD). SEEA and Transforming Global and National Statistical Systems for Monitoring SDG Indicators. In Proceedings of the Tenth Meeting of the UN Committee of Experts on Environmental Economic Accounting, New York, NY, USA, 24-26 June 2015.

12. United Nations Statistics Division (UNSD). The SEEA as the Statistical Framework in Meeting Data Quality Criteria for SDG Indicators; UNSD: New York, NY, USA, 2015.

13. Bann, C. Natural capital accounting and the Sustainable Development Goals. WAVES Policy Briefing. 2016, 1, $1-8$.

14. United Nations Committee of Experts on Environmental-Economic Accounting (UNCEEA). Broad-Brush Analysis of SEEA Relevant SDG Indicators; New York, 22-24 June 2016. Available online: https://unstats.un. org/unsd/envaccounting/ceea/meetings/eleventh_meeting/lod11.htm.

15. World Bank. Natural Capital Accounting; World Bank: Washington, DC, USA, 2016; pp. 1-4.

16. Vardon, M.; Lange, G.M.; Johansson, S. Achievements and Lessons from the Waves First 5 Core Implementing Countries; World Bank: Washington, DC, USA, 2016.

17. WAVES. Natural Capital Accounting and Policy Costa Rica. Available online: https://www.wavespartnership. org/sites/waves/files/kc/Costa\%20Rica\%20offer\%20doc_FINAL.pdf (accessed on 25 May 2018).

18. United Nations Statistics Division (UNSD). Revision of the System of Environmental-Economic Accounting (SEEA) SEEA Central Framework; UNSD: New York, NY, USA, 2012.

19. UNSD. Global Assessment of Environment Statistics and Environmental-Economic Accounting; UNSD: New York, NY, USA, 2007.

20. UNSD. Global Assessment of Environmental-Economic Accounting and Supporting Statistics 2014; UNSD: New York, NY, USA, 2015.

21. UNSD. Global Assessment of Environmental-Economic Accounting and Supporting Statistics 2017; UNSD: New York, NY, USA, 2018.

22. Edens, B.; de Haan, M.; Shenau, S. Initiating a SEEA Implementation Program-A First Investigation of Possibilities. United Nations Department of Economic and Social Affairs, Statistics Division. Sixth Meeting of the UN Committee of Experts on Environmental Economic Accounting, New York, ESA/STAT/AC.238, UNCEEA/6/19. Available online: http://unstats.un.org/unsd/envaccounting/ceea/meetings/UNCEEA-6-19. pdf (accessed on 17 June 2018). 
23. Aoki-Suzuki, C.; Bengtsson, M.; Hotta, Y. International comparison and suggestions for capacity development in industrializing countries: Policy application of economy-wide material flow accounting. J. Ind. Ecol. 2012, 16, 467-480. [CrossRef]

24. Naidu, S. Implementation of System of Environmental-Economic Accounting in the Pacific: Achievements and Lessons; United Nations Economic and Social Commission for Asia and the Pacific (ESCAP): Bangkok, Thailand, 2017.

(C) 2019 by the authors. Licensee MDPI, Basel, Switzerland. This article is an open access article distributed under the terms and conditions of the Creative Commons Attribution (CC BY) license (http://creativecommons.org/licenses/by/4.0/). 